\title{
Als de tekenen bedriegen.... : over beperkte rationaliteit en morele risico's in de berichtgeving
}

Citation for published version (APA):

van de Poel, J. (1988). Als de tekenen bedriegen.... : over beperkte rationaliteit en morele risico's in de berichtgeving. Wolters-Noordhoff. https://doi.org/10.26481/spe.19880304jp

Document status and date:

Published: 04/03/1988

DOI:

10.26481/spe.19880304jp

Document Version:

Publisher's PDF, also known as Version of record

\section{Please check the document version of this publication:}

- A submitted manuscript is the version of the article upon submission and before peer-review. There can be important differences between the submitted version and the official published version of record.

People interested in the research are advised to contact the author for the final version of the publication, or visit the DOI to the publisher's website.

- The final author version and the galley proof are versions of the publication after peer review.

- The final published version features the final layout of the paper including the volume, issue and page numbers.

Link to publication

\footnotetext{
General rights rights.

- You may freely distribute the URL identifying the publication in the public portal. please follow below link for the End User Agreement:

www.umlib.nl/taverne-license

Take down policy

If you believe that this document breaches copyright please contact us at:

repository@maastrichtuniversity.nl

providing details and we will investigate your claim.
}

Copyright and moral rights for the publications made accessible in the public portal are retained by the authors and/or other copyright owners and it is a condition of accessing publications that users recognise and abide by the legal requirements associated with these

- Users may download and print one copy of any publication from the public portal for the purpose of private study or research.

- You may not further distribute the material or use it for any profit-making activity or commercial gain

If the publication is distributed under the terms of Article $25 \mathrm{fa}$ of the Dutch Copyright Act, indicated by the "Taverne" license above, 
Als de tekenen bedriegen..... 



\title{
Als de tekenen bedriegen....
}

\author{
Over beperkte rationaliteit en morele \\ risico's in de berichtgeving
}

\section{Rede}

in verkorte vorm uitgesproken bij de aanvaarding van het ambt van hoogleraar in de Bedrijfseconomie aan de Rijksuniversiteit Limburg

\author{
op vrijdag 4 maart 1988
}

door

Dr. J.H.R. van de Poel

Wolters -Noordhoff Groningen 
1988 Wolters-Noordhoff bv Groningen, The Netherlands

Copyright $\odot$ J.H.R. van de Poel

Alle rechten voorbehouden. Niets uit deze uitgave mag worden verveelvoudigd $\mathrm{d}_{w}$ opgeslagen in een geautomatiseerd gegevensbestand, of openbaar gemaakt, in enige vorm of op enige wijze, hetzij electronisch, mechanisch, door fotocopieën, opnamen, of op enige andere manier, zonder voorafgaande schriftelijke toestemming van de uitgever.

All rights reserved. No part of this publication may be reproduced, stored in a retrieval system, or transmitted, in any form or by any means, electronic, mechanical, photocopying, recording or otherwise, without the prior written permission of the publisher. 


\section{Inhoud}

1. Berichtgeving en bedrog 7

2. Going concern 9

3. Accountability en beslissingsrelevantie 13

4. Agency-theorie 16

5. Regelgeving 20

6. Stelselkeuze 23

7. Accountantscontrole 27

Noten 33

Literatuur 41

Verantwoording 47 



\section{Berichtgewing en bedrog}

Tekenen kunnen bedriegen. Wie deze bekende zegswijze bezigt, dekt zich bij voorbaat in tegen een mogelijk verkeerde interpretatie van omgevingssignalen. Als de tekenen hem inderdaad bedrogen hebben, wast hij zijn handen in onschuld.

Mijn rede zal gaan over de 'tekenen' die door mensen gemaakte symbolen zijn'. Hun bedrieglijkheid kan woortkomen uit de wens van de maker om anderen zand in de ogen te strooien of op het verkeerde been te zetten. Dit zijn laakbare zaken ter voorkoming waarvan velen hun brood verdienen ${ }^{2}$. Het kan echter ook zijn dat de waarnemer zich gemakkelijk làat bedriegen; door oppervlakkige waarneming laat hij zich verleiden tot een foutieve interpretatie. Beide oorzaken voor het misverstaan zullen in mijn rede aan de orde komen.

Nietige thema's, zult u misschien denken, maar ze zijn van belang voor de beoefening van het vak bedrijfseconomie en in het bijzonder voor het bedrijfseconomische specialisme berichtgeving ${ }^{3}$ Dit specialisme houdt zich immers bezig met het onderzoek naar en het onderwijs in de berichtgeving als 'language of business', als taal van de economie. Voor de goede orde moet ik daarbij vermelden dat ik doel op 'economie' niet als wetenschap, maar als empirisch verschijnsel.

De 'language of business' heeft als functie het ondersteunen van de beeldvorming en de besluitvorming in de context van de zakelijke produktie en afzet van goederen en diensten. Gelet op de beperkte mogelijkheden van mensen om informatie te verwerken en rationele beslissingen te nemen, is het niet verwonderlijk dat zich in de loop van de tijd zoiets als berichtgeving heeft ontwikkeld. Het taalsysteem dat wij 'berichtgeving' noemen, en dat trekjes van een natuurlijke en nog steeds levende taal heeft ${ }^{4}$, is te beschouwen als een instrument om menselijke onvolkomentheid in cognitief opzicht te compenseren. In deze zienswijze ligt een analyse van de effectiviteit van de berichtgeving vanuit een cognitieve invalshoek al opgesloten. Het kan geen kwaad dit nog even te melden aan het adres van degenen die eraan twijfelen of het cognitieve onderzoek wel thuishoort in de berichtgeving. 
Net als bij de analyse van andere instrumenten voor menselijke communicatie, kan de cognitieve psychologie van pas komen bij het onderzoek naar berichtgevingsprocessen. In het cognitief-psychologisch onderzoek wordt de nadruk gelegd op de verwerking en niet op de produktie van tekens. Dat hangt vermoedelijk samen met de typische toepassingsgebieden van de psychologie: onderwijs, therapie, voorlichting en soortgelijke vormen van hulpverlening. In een ietwat paternalistische behandelling van hulpbehoevenden gaat het al gauw die kant op. Het object is immers meestal een mens die op de één of andere manier niet in staat is adequaat om te gaan met tekens uit de ongeving. Een groot deel van de psychologische toepassingen kan aldus worden opgevat als 'debiasingt, dat is het wegnemen van vertekeningen. Al haast ik mij hieraan toe te voegen dat juist in de psychologische literatuur vele fraaie staaltjes van reflectie te vinden zijn.

Een dergelijke concentratie op de verwerking van gegevens treft men binnen de bedrijfseconomie aan bij het cognitieve berichtgevingsonderzoek dat ook wel wordt aangeduid als "human information processing'. Ook hier ligt de nadruk op het verkeerd verstaan van tekenen. In de berichtgeving wordt evenwel een grotere plaats ingeruimd voor de produktie van gegevens. Zelfs zo'n grote plaats, dat er wetten en andere voorschriften gemaakt zijn die deze gegevensproduktie in bepaalde banen trachten te leiden. Ook het onderwijs in de berichtgeving staat in dit teken. Dit heeft niet alleen te maken met het opheffen van cognitieve beperkingen, maar ook met het feit dat de berichigeving een tweede hoofdtaak heeft namelijk die inzake het afleggen van verantwoording over het reilen en zeilen van organisaties. De maatschappelijke functies van de berichtgeving omvatten ook het registreren van rechten en plichten terzake van eigendom. Dit komt wel het duidelijkst tot uitdrukking in het boekhouden, dat beschouwd kan worden als de basis van de berichtgeving als kunde'. Deze orientatie op de registratie van eigendomsrechten brengt een zekere bezorgdheid over 'valsheid in geschrifte' met zich mee.

In de zogenaaunde 'agency-theorie' wordt aan bedrog nim aandacht geschonken. Uitvocrders, lasthebbers, of hoe men agenten verder ook moge aanduiden, worden geacht hun eigen belangen te laten prevaleren 
boven die van hun principalen. Het knoeien met gegevens en rapportage omtrent inspanningen die ten behoeve van de principaal zijn verricht, alsmede de resultaten daarvan, wordt derhalve tot de mogelijkheden gerekend. Het zijn echter de verwerking en de cognitieve beperkingen die daarbij inherent optreden, die de grond vormen waarin het zaad van de vertekening gezaaid kan worden door malafide producenten wan informatie. Juist het bedrog dat zich weet te verbergen achter de sluier van de plausibiliteit, is effectief. Hier zijn vele voorbelden van te geven die rechtstreeks verband houden met de beoefening van de bedrijfseconomie. Voordat ik enkele daarvan geef, zal ik echter mijn intentie kort samenvatten. Het gaat mij om een verkenning van een tweetal onderzoekbenaderingen of theorieèn zo men will. De ene is het cognitieve berichtgevingsonderzoek, de andere is de 'agency theory'. In de cerste ligt de nadruk zoals gezegd op het werkeerd verstaan van tekenen en in de tweede gaat het om het al dan niet opzettelijk vertekenen van berichten met de bedoeling dlaar beter van te worden. Beide benaderingen zijn relevant voor de analyse van berichtgevingsprocessen, maar zij worden zelden met elkaar in verband gebracht. Beide worden door veel beofenaren van de bedrijfseconomie om uiteenlopende redenen met enige argwaan bekeken. Ik heb niet de pretentie deze twee benaderingen in één rede met elkaar te integreren, maar ik vind wel dat zoiets cen goed uitgangspunt kan zijn voor het verrichten van onderzoek.

\section{Going concern}

Plausibiliteit is een belangrijke bron van problemen bij het hanteren van de zogenaamde 'going concern'-veronderstelling bij de 'voortgangsrapportage' van riskante projecten. Jaarrekeningen en jaarverslagen worden doorgaans gebaseerd op dit 'principe' dat inhoudt dat aangenomen wordt dat de onderneming een toekomst heeft die voorbij de planningshorizon reikt. Maar de beoordeling van de continuiteit moet wel vertekenbaar zijn als de basis in hoofdzaak een historische is. Immers, de voortgangsrapportage heeft maar al te vaak het karakter van een historisch overzicht. De jaarverslaggeving door ondernemingen heeft in ieder geval dit karakter en de wettelijke eisen die gesteld zijn aan het ontvouwen van toekomstperspectieven zijn tot nu toe weinig effectief gebleken. 
De going concern-veronderstelling wordt niet alleen aangetroffen in de externe verslaggeving van ondernemingen, maar manifesteert zich in ieder riskant project. Ieder project, iedere 'ondememing" loopt het risico dat het mislukt. De 'wereld" is immers onzeker en je weet maar nooil. In de sociale context - war de bedrijfseconomie zich op richt - is het echter niet zo zeer de "natuar" die onzekerheden schept, als wel de 'cultuur': de medemens neemt beslissingen en velt oordelen die van invloed zijn op de uitkomsten van projecten. Leiders van riskante. projecten beseffen terdege dat hun rapportage over de ontwikkeling van het project van invloed is op dat risico. Er zijn namelijk bij ieder project interne en externe betrokkenen die individueel of gezamenlijk kunnen besluiten hun handen af te trekken van het project, waardoor hun bijdrage, hetzij fysiek, hetzij in de vorm van steun, wegvalt en het project beeindigd moet worden. Slecht nieuws is daarom in veel gevallen desastreus voor de voortzetting. Slecht nieuws wordt om die reden uitgesteld tot het allerlaatste moment. En omdat dit een cultuurtrekje is geworden, doet zelfs de eerlijkste verslaggever er beter aan om negaLieve details niet te rapporteren. Want juist omdat de omgeving niet gewend is aan negatieve informatie over de voortgang, zal iedere kleinigheid opvallen en aanleiding kunnen zijn voor een zodanige bijstelling van subjectieve risicoschattingen dat men zijn participatie in het project beëindigt.

Al te veel eerlijkheid is ook rampzalig in het kader van de budgettering. Welke afdelingschef of divisiedirecteur zal niet eerst proberen een probleem op te lossen of uitstel te verkrijgen in de hoop dat het 'vanzelf' wel over gaat? Welke minister zal niet tot het laatste moment wachten met thet toegeven dat een bepaalde maatregel niet goed uitgevoerd kan worden? Uiteraard zijn er in veel van dit soort potentiele conflict-situaties regels die pogen het gedrag van rapporteurs te beheersen. Wat verboden is, is derhalve laakbaar en kan bestraft worden. Maar het blijft te allen tijde moeilijk om in dit verband een onderscheid te maken tussen 'harde" en 'zachte' fraude. In de harde fraude gaat het om doelbewuste vertekening van informatie teneinde iets te bereiken door lets te tonen wat er niet is of iets te verbergen wat men voor zich wil houden, terwijls zulks uitdrukkelijk verboden is door wetten, overeenkomsten of goede zeden. Maar ook als er geen criminele handeling, contractbreuk of wanprestatie in het geding is, kan de verstrekker van 
informatie door middel van valse voorlichüng proberen zijn eigen belangen te behartigen ten detrimente van anderen. Is dit minder crimineel en derhalve aan te merken als zachte fraude? Hoe zit het met het bekende budgetgedrag warin majoreren, verschrijven, 'smoothing', overconsumptie van 'gratis' ter beschikking gestelde diensten en strategisch gedrag 5 aan de orde zijn? Hoe scherp is de grens tussen hard en zacht in dit verband? Ik weet het niet, maar wel weet ik dat de bedrijfseconomische analyse wan organisaties en andere samenwerkingsverbanden, er niet omheen kan deze 'morale risico's" in haar beschouwing te betrekken. Daarbij vallen mij in ieder geval twee dingen op: (1) tekenen bedriegen vaak uit hoofde van heimelijke acties met het doel daar beter van te worden en (2) tekenen kunnen slechts bedriegen als de ontvanger van de informatie zijn zinnen laat begoochelen. In al deze gevallen zal de rapporteur zijn verslag zo willen inrichten dat het plausibel is en samenvalt met de goede hoop van de ontvangers van de informatie. Met andere woorden, de entropie van de informatie moet minimaal $z_{i j n^{6}}$. Het is in dit verband overigens niet uitgesloten dat de rapporteur zelf lijdt onder een "illusion of control" door zijn eigen mogelijkheden verre te overschatten ${ }^{7}$. Hij geloof er zelf ook in, dikwijls geholpen door een misplaatst commitment jegens andere betrokkenen ${ }^{8}$.

Blikens Hoogendoom's ${ }^{9}$ analyse van het jaarrekeningbeleid van RSV, kan een in het nauw gedreven ondememingsleiding zich inderdaad door dit soort factoren laten beinvloeden. Enerzijds gelooft men in de eigen mogelijkheden, bijwoorbeeld bij het schatten van toekomstige tegernvallers, anderzijds is men zo pessimistisch als het maar kan, bijvoorbeeld door aan te nemen dat de zogenaamde 'bijzondere achtergestelde leningen" nimmer zullen worden terugbetaald, zodat ze gebruiki kunnen worden om het balansbeeld op te poetsen. De surseance van RSV was in ieder geval niet uit de gerapporteerde cijfers af te leiden. De ondernemingsleiding wachtte tot het allerlaatste moment mat het verstrekken van negatieve informatie. Het gedrag van de RSV-leiding vertoont overeenkomsten met het manisch -depressieve ziektebeeld. Maar de eerlijkheid gebiedt ook te zeggen dat het analyseren achteraf gemakkelijk is. Het aanwijzen van oorzaken en schuldigen berust ten dele op een "hindsight bias".

Wat is de rol van de wetenschappelijke analyse in dit verband? Om te 
beginnen kunnen we constateren dat sommige academische bedrijfs economen ${ }^{10}$ al in een vroeg stadium duidelijk hebben gemaakt dat de externe berichtgeving door ondememingen geen puur historisch verslag kan zijn. De jaarwinst van cen ondememing is blijkens de analyse geen historisch feit, maar staat mede onder invloed van de toekomstverwachtingen van de ondememingsleiding, lsmede vain de ondernemingsdoeleinden. Wil het 'accounting concept of profit' een redelijke benadering zijn van het 'cconomic concept of profit', dan dienen er derhalve mededelingen gedaan te worden omtrent de perspectieven en de doeleinden. Toen Bouma dit in 1967 probeerde uit te leggen aan de verzamelde Nederlandse registeraccountants ${ }^{11}$ werd hij door een deel van zijn gehoor nog voor "communist' versleten, maar inmiddels hebben we in dit land wetgeving die de onderneming verplicht een jaarverslag, ook wel 'directieverslag' genoemd, te publiceren. De kwaliteit van deze jaarverslagen lat echter wel te wensen over ${ }^{12}$. Ondememingsleidingen bliken slecht te kunnen voorspellen. Hun voorspellingen zijn bovendien veelal optimistisch. Verder blijkt dat ondernemingen meer prospectieve informatie verschaffen als er gunstige vooruitzichten zijn. Geen bericht, slecht bericht. Als het goed gaat is er niets te verbergen. Weer die merkwaardige mengeling van eigenbelang en cognitieve factoren.

In het voorgaande heb ik enkele verschijnseten besproken die niet voorkomen in het jargon wan de traditionele bedrijfseconomie. Ik heb gerefereerd aan de fenomenen 'hindsight bias', 'selectieve perceptie", 'illusion of control' en 'wishful thinking', alle vier heuristicken of vuistregels die blijkens empirisch onderzoek ten grondslag kunnen liggen aan vertekeningen in de menselijke oordeelsvorming. Er zijn vele van dit soort vuistregels ${ }^{13}$, maar het ontbreekt vooralsnog aan een uitputtende en definitieve classificatie. Evenmin is de aanwezigheid van vuistregels altjd gemakkelijk aan te tonen, laat staan hun vertekenende werking. Zij zijn echter de eerste linie war de bedrijfseconomie in aanraking komt met cognitieve aspecten die ook door andere disciplines worden onderzocht.

Het wetenschappelijk onderzoek van berichtgevingsprocessen heeft zich de laatste jaren meer en meer bezig gehouden met cognitieve aspecten. In de zogenaamde 'human information processing'-studies wordt ge- 
tracht te achterhalen wellke factoren werantwoordelik zijn voor het ontstaan van vertekeningen in de beeldvorming. Dit soort onderzoek is aiteraard multidisciplinair omdat het een combinatic is van cognitieve psychologie en bedrijfseconomie. Het is multidisciplinair in de ware betekenis van het woord ondat het geen mechanistische toepassing van de psychologie is. Dat laatste is in de eerste plaats niet mogelijk ondat een meer dan oppervlakkige kennis van de betreffende verschijnselen vereist is en het zijn nu eenmaal de bedrijfseconomen die in de academische wereld deze kennis (behoren te) hebben. In de tweede plaats kan het onderzoek niet wit de voeten als het niet rekening houdt mat (bedrijfs)economische theorieèn omtrent besluitvorming, control en verantwoording. Over deze laatste wil ik het nu hebben.

\section{Accountability en beslissingsrelevantie}

Mede door de opkomst van besliskunde en beslissingstheorieen heeft de laatste decennia de opvatting postgevat dat het de bolangrijkste functie van de berichtgeving is te zorgen woor een goede onderbouwing van beslissingen door belanghebbenden in de onderneming. Aandeelhouders, banken, werknemers, leveranciers, overheidsinstanties, afnemers, omwonenden en zelfs actiegroepen, hebben behoefte aan informatie over het reilen en zeilen van de onderneming. Zij allen nemen beslissingen warvan de kwaliteit mede afhangt van de kwaliteil van de verslaggeving. Ook de interne processen inzake coördinatie, planning en beheersing, worden geacht in kwaliteit te variëren alhankelijk van de kwaliteit van de informatie. Deze opvatting wordt wel aangeduid als het 'decision relevance' paradigma dat niet alteen aansluit bij de beslissingstheorieèn, maar ook bij de eerdergenoemde cognitiefpsychologische benadering. Immers, behalve de analyse van de syntactische en de semantische aspecten door de klassieke leer van waarde, kosten en winst, al dan niet geworteld in de economische theorie, en eventueel aangevuld met de thans alom anwezige juridische beschowwingen, kan ook van de cognitieve anpak vrij gemakkelijk verwacht worden dat zij bijdraagt aan de bestudering en oplossing van allerlei vraagstukken die verband houden met beslissen en informeren. Het is dan ook geen wonder dat vrijwel alle leerboeken in hun inleidingen refereren aan dit decision relevance paradigma. Maar helaas blijft 
bij dit denkbeeld een belangrijk aspect buiten beschouwing. Laat mij, om dit te illustreren, kort stil staan bij enkele problemen die een verse afgestudeerde zou ontmoeten als hij of zij uitsluitend grootgebracht was miet decision relevance.

Onze jonge doctorandus zal geleerd hebben dat er 'sunk cost ${ }^{14}$ bestaan, dat wil zeggen, kosten die wèl in de administratie opduiken, maar die niet relevant zijn bij de besluitvorming, bijvoorbeeld de investeringskosten van een lopend project. Hij heeft geleerd deze informatie niet te gebruiken, maar hij constateert tot zijn schrik, dat de onderneming waar hij werkt deze investeringskosten (laten we maar zeggen afschrijvingen) doorberekent aan afdelingen, dochters en divisies.

Een collega van onze jonge doctorandus, ook net afgestudleerd, maakt iets mee wat onk niet in de boeken stond: er worden in zijn bedrijf mensen verantwoordelijk gesteld voor kosten die zij in het geheel niet kunnen beheersen. "Dit is toch in strijd met het principe dat mensen nooit op hun brood mogen krijgen wat zij niet kunnen beïnvloeden', roept onze jonge vriend, 'bovendien, het bederft hun motivatie grondig' 15 .

Wat deze fictieve studenten niet geleerd hebben, is dat het niet zo zeer de beslissingsondersteuning is waar de berichtgeving voor heeft te zorgen, maar vooral het afleggen van verantwoording, het motiveren en het beheersen. Deze aspecten worden gewoonlijk samengevat in de begrippen 'accountability' en 'stewardship'. In deze begrippen wordt tot uitdrukking gebracht dat de informatie die de berichtgeving heeft te verzorgen ontleend is aan en bestemd is voor het laten verlopen van verantwoordingsprocessen in een organisatorische context. Het begrip stewardship duidt aan dat het daarbij kan gaan om rentmeesterschap: de rentmeester beheert cen object ten behoeve van een eigenaar die bij tijd en wijle op de hoogte wil worden gesteld van de gang van zaken en die tevens door middel van het afleggen van rekenschap door de beheerder, enige preventieve grip heeft op de gang van zaken. Het berichtgevingssysteem - dat veelal deel uitmaakt van het contract dat de heren gesloten hebben - brengt orde en discipline in het beheer. Afhankelijk van de situatie en de doeleinden van beide partijen, alsmede van de capaciteit van de uitwoerder, kan het in dit verband gewenst zijn een 
contract te sluiten waarin de verantwoordelijkheid voor onbeheersbare kosten inderdaad voor rekening van de uitvoerder komen. De reden kan bijvoorbeeld zijn dat beiden het eens zijn over een risico-deling die de eén in staat stell meer vertrouwen te hebben in het beheer en de ander een kans geeft zijn beloning te verhogen door het desbetreffende risico af te dekken, uit te sluiten, of te ontwijken. Dit laatste kan niet zonder enige innovatie en dat is precies de bedoeling van de regeling: de uitvoerder een motief te verschaffen om goed op to letten en nieuwe beheersactiviteiten te ontwikkelen.

Het geval van de sunk cost kan op soortgelijke wijze werklaard worden. Er kan zich namelijk een moreel risico voordoen waarbij geanticipeerd wordt op sunk cost. Ook in dit geval moeten we dan rekening houden met de organ"satorische context waarin onder meer bevoegdheden worden gedelegeerd, dat will zeggen, er wordt gelhandeld voor rekening van anderen. Indien nu de gedelegeerden niet belast worden voor het gebnik van investeringsgoederen, bestaat de kans dat zij dit intensiever zullen doen dan wanneer er wèl een prijs betaald moet worden. Ook is bij niet-belasten, zeg 'gratis' gebruik, de kans groter dat de overconsumptie leidt tot een verkeerde perceptie van de vereiste capaciteit. Lichtzinnigheid bij investeringsbeslissingen kan het gevolg zijn 16 .

Er is in de literatuur enige discussie over de beste atanpak van dit soort verschijnselen. Er zijn ruwweg twee stromingen. De cerste is die van de economische analyse waar begrippen als 'contracting', 'agencykosten' en 'transactiekosten' gehanteerd worden. Uit mijn beschrijving van zoëven kunt u afleiden dat ik mij niet ongaame van dit jargon bedien. De aanhangers van deze economische benadering hebben in het algemeen een voorkeur woor deductie, hypothesevorming en -toetsing; zij gebruiken vaak een econometrische analyse en weten dikwijls geen raad met weldwerk. De tweede stroming zou ik willen kenschetsen als sociologisch en misschien wel antropologisch; zij is meer inductief van aard en bedient zich vaak van weldwerk, case-beschrijvingen, directe waarneming en participerende-observatie. Naar mijn overtuiging zijn beide benaderingen nutig en het is daarom te betreuren dat zij zich zo slecht met elkaar verstaan. Vermoedelijk spelen daarbij enige sentimentele en ideologische motieven een rol. Misschien ziet men elkaar als mededingers. Wie zal het zeggen? 
Ik zou gaame dieper ingaan op de mogelikheden die er zijn on beide benaderingen tot elkaar te herleiden, maar het woert te ver mij op dexe plaats aan een dergellike exercitie over te geven 17 . Geconcludeerd kan worden dat beide stromingen het eens zijn over het nut van het 'decision rellewance' paradigma: het wordt namelijk door beide afgewezen. Ook hebben beide oog voor de mogelijkheden die informatiesystemen bieden aan gebruikers om door middel van vertekeningen en zachte fraude anderen zand in de ogen we strooien. Wat bij de én 'moral hazard' heet, is bij de andere 'pursuit of power and influence". Wat bij de een 'accountability' of 'agency' heet, noemt de ander het 'institutional perspective, which stems from the need to put on an appropriate facade for the world to see 18 . Gaan we er wan uit dat cen specialisatie - zij het naar empurisch object, zij het naar paradigma niet zonder enige theorievorming kan, en nemen we aan dat deze vorm van produktie zowel via deductie als inductic inderdaad tot theorieern moet leiden, dan is er veel gewonthen. Houden we ook nog - met Boumat - rekening met de omstandigheid dat berichtgeving zich op drie taken heeft te richten ${ }^{19}$; te weten:

- praktische toepassing waarbij kennis omgezet wordt in actie;

- onderwijs waarbij dergelijke kennis wordt doorgegeven;

- reflectie waarbij deze kennis wordt geproducerd, onderhouden en geperfectioneerd,

dan is duidelijk dat enige coördinatie door middel van aprioristische methodlen geen kwaad kan. De 'agency theory' is op dit moment een van de betere kandidaten om dat te bereiken.

\section{Agencywheorie}

Dankzij de voortreffelijke samenvattingen van onder andere Barkema, Douma, Moerland en Schreuder 20 is de agency theory redelijk bekend in Nederland. Ik zal daarom volstaan met een korte omschrijuing van deze theorie.

De agency-theorie gaat uit van een situatic warin een principaal of lastgever een overeenkomst sluit met een agent of lasthebber. Dit contract kan formeel en expliciet zijn, mas hat kan ook een stilzwijgend en gemeenschappelijk gevoel zijn. In het contract geeft de 
principaal de agent opdracht om iets voor hem te doen. De agent is om witeenlopende redenen beter in stat het doel van de principaal te bereiken, dan de principaal zelf. De agent beschikt over een bepaalde deskndigheid die de principaal niet heeft. Als tegenprestatie ontvangt de agent een vergoeding. Deze vergoeding $\mathrm{kan}$ in meerdere of mindere mate gekoppeld zijn aan de mate waarin het doel van de principaal word bereikt. De vergoeding kan ook in meerdere of mindere mate gebaseerd worden op de inspanning die de agent verricht. Deze inspanning kan op verschillende manieren gemeten worden. Bijvoorbeeld de tijd die de agent vrij maakt voor het witwoeren wan zijn taak. Of de tijd plus een correctie woor de intensiteit waamee de agent zijn plicht verwult.

De aldus omschreven theorie roept existentiele vragen op. Bijvoorbeeld: hoe komt het dat er agenten en principalen zijn? Wat maakt de én tot principaal en de ander tot agent? of - in het verlengde hiervan waarom bestaan ondememingen en waarom zijn zij hierarchisch gestructureerd? Deze vragen werden niet voor het eerst gesteld, maar de aanhangers van de agency-theorie deden hun best om andere antwoorden te formuleren. Het antwoord ${ }^{21}$ werd dat het bestaan van teamproduktie het gevaar wan 'shirking' in zich bergt en dat het daarom gewenst is enige 'monitoring' toe te passen. De monitor zou zich echter zelf ook kumnen drukken en dat werklaart warom zijn beloning 20 sterk afhankelijk is gemaakt van de onzekere resultaten 22 .

Welke beloningsformule in het contract terechtkomt hangt af van een drietal factoren. In de eerste plaats verricht de agent zijn werk in een onzekere wereld. De resultaten van zijn inspanningen zijn derhalve afhankelijk van omgevingsrisico's. In de tweede plaats kan de principaal niet kosteloos alle informatie krijgen over de toestand op ieder moment. Zowel de inspanning van de agent als de toestand van de wereld onttrekken zich goeddeels aan zijn waarneming, dat wil zeggen, er is 'limited observability'. Weliswaar bevat het contract doorgaans regels over de wijze van registreren en rapporteren, maar perfect is deze "monitoring" niet. In de derde plaats heeft de agent - hoe goed hij het ook voor heeft met de principaal - een broertje dood aan werken. Indien de kans zich voordoet, drukt de agent zich (shirking'). Enige zachte en soms ook wel harde fraude is de agent niet vreemd. Hij zal vooral niet 
nalaten de omstandigheden de schuld te geven van eventuele slechte resultaten. Er is immers onzekerheid waaronder het werk moet worden gedaan, dus is er altijd wel gelegenheid on tegenvallers daaraan toe te schrijven. Dit derde aspect wordt aangeduid als "moral hazard".

Het laatste punt heeft relaties met de attributietheorie uit de psychologie. Het is bepaald niet alleen de economische analyse die 'moral hazard' situaties verklaart, er zal ook naar de psychologische effecten gekeken moeten worden. Uit alles blijkt namelijk dat mensen geneigd zijn successen aan zich zelf te wijten en hun mislukkingen aan anderen en aan de omgeving. Het onderzoek dat gebaseerd is op de attributietheorie is niet alleen een interessante aanvulling op de agency-theorie, maar kan ook leiden tot betere verklaringen van disfunctioneel gedrag, contracting en resultaatmeting 23 . Iedere benadering die in plaats van nutsmaximalisatie aan te nemen, voorkeuren en attitudes empirisch tracht te analyseren, is in principe een aanwinst voor de agency-theorie en andere economische organisatietheorieën ${ }^{24}$.

De economie zit vol met agency-relaties. Niet alleen in de formele, maar ook in de informele sfeer. Niet alleen in zakelijke organisaties, maar ook in gezinnen, buurten en clubs. Er zijn voorbeelden te over. Bijvoorbeeld de patiènt die de arts als agent inschakelt. Of de baas die zijn knecht opdrachten geeft. De huisvrouw die haar huisgenoten laat af wassen. Of de verzekeringsmaatschappij die haar verzekerde opdraagt 'goed op te passen'. En de aandeelhouders die hun directie opdragen een rendement op het geïnvesteerde vermogen te behalen.

Hoe kan men deze agency-relaties, deze 'contracting'-processen analyseren? Zoals met iedere theorie kan men op verschillende manieren te werk gaan. Er zijn in de bedrijfseconomie drie methoden te onderscheiden $^{25}$ :

1. de aprioristische methode waarbij op deductieve wijze uit een aantal meer of minder plausibele premissen conclusies worden afgeleid ${ }^{26}$; de tak van de agency theory die zich hiermee bezig houdt wordt meestal aangeduid als 'principal-agent' onderzock 27 ;

2. de deductief-hypothetische methode waarbij op grond van onvolledige waarneming hypothesen worden geformuleerd waaruit langs deductieve weg implicaties worden afgeleid die als voor- 
spellingen getoetst worden aan nieuw empirisch materiaal ${ }^{28,}$, de zogenaamde 'positieve' agency-theorie hanteert deze methode ${ }^{29}$;

3. de interactieve methode waarbij de nadruk ligt op de communicatie tussen onderzoeker en object teneinde beider doeleinden gezamenlijk te bereiken; het object wil bepaalde problemen oplossen waarbij de onderzoeker kan helpen, terwijl de laatste tevens in het bezit komt van data en ervaringen die hem kunnen helpen hypothesen te formuleren 30 .

Voorzover ik kan nagaan laat de agency-theorie het aan ieder wan ons over wellke methode wij willen gebruiken. Ook staat het ons vrij op punten af te wijken van het paradigma. Met Van Rossum (1985) en Schreuder (1985) zou ik de niet-restrictieve interpretatie van de bedrijfseconomie willen bepleiten ${ }^{31}$, maar als het even kan zal er toch een soort synthese beschikbaar moeten zijn van waaruit de ronddolende onderzoeker vertrekt op zoek naar het avontuur en waarheen hij terug kan keren. Ik vind de agency - theorie geschikt voor dat doel - ik kom daar straks op terug - al kan ik mij voorstellen dat sommigen kritiek willen geven. Mijn eigen kritick heeft vooral betrekking op het ontbreken van het cognitieve element in de standaard agency-theorie. Met name de rationaliteitsveronderstellingen gaan geheel voorbij aan de conclusies die de gedragswetenschappelijke benadering in de bedrijfseconomie de laatste decennia heeft weten te trekken. De mogelijkheden om zulks te doen liggen voor het oprapen. Zo ligt het voor de hand om te analyseren welk effect het hanteren van aspiratieniveaus heeft op het contracting-proces. Dat er in veel agency-situaties met aspiratieniveaus gewerkt wordt is bekend. In het kader van de budgettering bijvoorbeeld, worden verwachtingen ten aanzien van de uitkomsten gecreëerd, tenminste impliciet en in veel gevallen zelfs expliciet. Dit heeft psychologische effecten - zowel cognitieve als andere - die niet gemakkelijk kunnen worden voorspeld 32 . De mainstream agency theory lat deze factoren echter buiten beschouwing, aannemend dat de effecten in een grote steekproef tegen elkaar wegvallen. Gezien de grote praktische belangen in dit verband is het evenwel niet verantwoord zolets af te doen met een veronderstelling. Wellicht dat de macro-orientatie van de huidige agency-theorie hier iets mee te maken heeft. Men aggregeert graag en veel. 
Op allerlei plaatsen in de bedriffeconomie wordt de agency-theorie thans toegepast. In de financiering, de berichtgeving en de organisatiekunde zijn interessante toepassingsgebieden ontsloten. Laat ik mij bij het geven van een voorbeeld evenwel beperken tot de berichtgeving.

\section{Regelgeving}

Tot nu toe heb ik geen onderscheid gemakakt tussen 'inteme' en 'externe' berichtgeving. Ik zal proberen dat zo te houden. Naar mijn oordeel - en gelukkig ook naar dat van Anthony ${ }^{33}$ - is cen dergelijk onderscheid niet gewenst. Het hindert het zicht en brengt de externe verslaggeving te dicht bij het vaarwater van de juristen. Dit vaarwater is - zoals bekend vol mijnen. Weliswaar gaat de 'public choice' benadering mee als mijnopruimingsdienst, maar het blijft uitkijken. Liever zie ik de juristen het ruime economische sop kiezen. En nu we het er toch over hebben, zijn er niet teveel maatschappelijke regels waar juristen teveel en economen te weinig vat op hebben? ${ }^{34}$

Een theoretische analyse van de regelgeving op het gebied van de externe berichtgeving verschilt in de grond nawwelijks van een analyse van het interne beheersingsvraagstuk. In beide gevallen gaat het om een agency-situatic en derhalve om de vraag hoeveel bevoegdheden gedelegeerd kunnen worden. In beide gevallen gaat het om het beheersen van gedrag en om contracten waar minstens evenveel 'politiek' aan te pas komt als analyse ${ }^{35}$.

Het onderzoek naar de totstandkoming en het nut van de huidige regelgeving is in Nederland weinig ontwikkeld. Naast een algemene achterstand op het terrein van de 'positive accounting research' zijn er bijzondere redenen zoals het gebrek aan openbare gegevens over onderhandelingsprocessen inzake de regelgeving. Uiteraard worden onze wetten dankzij de democratie op doorzichtige wijze behandeld en vasigesteld in openbare vergaderingen, maar het fijnzinnige 'voortraject" is in duisternis gehuld. Zo is moeilijk te vinden welke standpunten door de diverse accountantskantoren zijn ingenomen. Dit is in de Verenigde Staten anders, waar zogenaamde 'opinions" worden gepubliceerd. Om een idee te krijgen van de mogelijkheden van het agency- 
onderzoek naar de berichtgeving, moeten wij ons dus behelpen met. Amerikatanse publicaties terzake.

De positive accounting theory 36 probeert de keuze wan waarderingsprocedures en -grondslagen te verklaren met behulp van de agencytheorie. Zij is een woortzetting wan het economische berichtgcvingsonderzoe $k^{37}$ dat zich sinds de jaren zestig baseert op de 'efficiente markthypothese', maar dat niet tot eenduidige resultaten kwam.

Het onderzoek komt dichter in de buurt van het agency-model als de vraag gesteld wordt hoe sommige systematische werschillen tussen sectoren verklaard zouden kunnen worden. Ook het feit dat de externe berichtgeving door banken gebruikt kan worden om faillissementsrisico's te schatten, wijst erop dat deze gegevens invloed hebben op de wijze waarop contracten worden gesloten en uitgevoerd. De belangrijk ste redenen om de "information content'-benadering in twijfel te trekken komen echter voort uit het debat over de regelgeving ${ }^{38}$. Immers, de efficiente-mark thypothese leidt tot de conclusie dat regelgeving weinig $z$ in heeft, terwijl het verschijnsel wel bestat. Hoe is dit te verkJaren?

De rationalisaties van de inmenging door de overheid zijn in hoofdzaak beschouwend en weinig empirisch onderbouwd. De argumenten zijin bijwoorbeeld: (1) dat het management een monopolicpositie heeft ten aanzien van de verstrekte gegevens; (2) dat beleggers naief zijn; (3) dat sommige gegevens geen betekenis hebben en slechts bedoeld zijn om participanten op het verkeerde been te zetlen of te vermoeien; (4) dat er te veel verschillende procedures worden gehanteerd; en (5) dat de gegevenswerstrekking niet objectief is ${ }^{39}$. Zonder empirische anallyse, zijn de "bewijzen" van het tegendeel echter ook te geven. "Voor hetwelfde geld' kan men tot de overtuiging komen dat regelgeving overbodig is. De meeste van de genoemde gedragseffecten worden namelijk, ook in hoorie, door de markt afgestraft.

Andere argumenten voor regelgeving, maar evenmin empirisch onderbouwd, gaan uit van het bestaan van 'market failures' die er toe leiden dat de hoeveclheid verstrekte informatie afwijkt van een of ander matschappelijk optimum. Bijvoorbeeld door:

1. aan te nemen dat berichtgeving een collectief goed is doordat 
ondernemingen net in staat zijn niet-betalende gebrukers uit te sluiten wardoor er onderproduktue ontstaat bij afwezigheid van regelgewing;

2. berichtgevingsinformatie op te vatten als 'signaling 40 waarbij een ondememing wier aandelen ondergewaardeerd worden het voordelig vindt om additionele informatie te verstrekken atan de beleggers met als gevolg overproduktie van berichtgeving:

3. rekening te houden met overproduktie van informatie door outsiders met speculatieve intenties waardoor geen recle maar wel herverdelingseffecten kunnen optreden.

Behalve dat het empirisch bewijs van deze stellingen ontbreekt, kan de woorstanders van interventie ook tegengeworpen worden dat zij er impliciet wanuit gaan dat de overheid beschikt over het inzicht dat noodzakelijk is om het maatschappelijke optimum te identificeren. Een ander bezwaar is dat nagelaten wordt de non-market failares even kritisch te analyseren als de market failures ${ }^{41}$. Van een onvertakende afweging kan dan geen sprake zijn. Het criterium kan niet anders dan de contracting-kosten zijn. Slechis indien deze bij overheidsinterventie lager zijn dan zonder, heelt regelgeving zin. Dit geldt ook voor het signaling-probleem: als geen contracting-kosten zijn is er geen reden voor signaling en als ze er wel zijn, draait alles om de vraag of de particuliere kosten hoger zijn dan die van de overheid. Ook het speculatie-argument kan op deze wijze aangevochten worden: telkens als producenten en consumenten bepaalde onzekerheden willen reduceren, ontstaat er behoefte aan lieden die op grond van hun voorspellingen deze onzekerheden enigszins kunnen beheersen. De informatie die daarbij geproduceerd wordt, kan bezwaarlijk sub-oplimaal genoemd worden.

De kosten van de regelgeving bestaan niet alleen wit de directe kosten wan het maken en handhaven van regels, het produceren van verslagen die aan de wettelijke eisen voldoen, het lobbyen over de regelgeving en gerechtelijke procedures van allerlei aard die uit dit alles kunnen voorkomen, maar ook uil de indirecte kosten die verband houden met produktie- en financieringsbeslissingen. Deze kosten zijn grotendeels onbekend en worden traditioneel niet in de beschouwing betrokken. Dit geeft te denken, want hoe zou mein voorbij kunnen gaan aan dergelike 
belangrijke factoren. Geen wonder dat getwijfeld wordl aan het doel van de regelgeving: gaat het echt om het opheffen wan specifieke market failures of vormt het belang van politici en ambtenaren de betere verklaring voor het bestaan van de interventie?

\section{Stelselkeuze}

Waarom zou de ondememingsleiding in verslaggeving geinteresseerd kumnen zijn? In de agency-theorie wordt het antwoord gevonden in de voor- en nadelen van contracten die de leiding gesloten heeft mel (1) de eigenaren; (2) de verschaffers van wreemd vermogen; en (3) de overheid. Regelgeving en contracten beperken de keuze van verslaggevingsregels, maar zelden is die keuze zo beperkt dat er niets meer te kiezen valt. De ondernemingsleiding maakt een keuze uit de verzameling toegestane regels. Deze verzameling wordt in eerste instantie bepaald door maatschappelijk aanvaarde normen en wettelijke voorschriften ("set of accepted accounting rules') en in tweede instantie door de overeenkomsten dic de leiding voor zich zelf of voor de ondememing heeft gestoten met banken en aandeelhouders. Het gaat er dus om de stelselkeuze in verband te brengen met winstdelingsregelingen, leningsvoorwaarden, ontwikkelingen van de beurswaarde en lobby-activiteiten rond de regelgeving.

Winstdelingsregelingen worden vaak gebaseerd op accounting profit en niet op beurswaarde. Hiervoor zijn verschillende redenen. Een reden is bijvoorbeeld dat er geen beursnotering is voor bedrijfsonderdelen (dochters en divisies), terwijl de managers van deze onderdelen ook vaak een winstdelingsregeling hebben. Bovendien heeft de berichtgewing ook een interne functie - onder andere voor de motivatie van interne participanten - en dat geeft de ondenemingsleiding enige ruimte voor invulling. Een plausibele bypothese ten aranzien van winstdeling is derhalve dat de leiding belang heeft met resultaten te schuiven. Dit is de zogenaande 'bonus-plan' hypothese. Zo kan het woordelig zijn toekomstige resultaten naar woren te halen, dan wel hudige resultaten te drukken omdat er bijvoorbeeld een plafond is gesteld aan de bonus. De resultaten die uitgaan boven dit plafond kan men beter voor later bewaren. Ewenzo kan het nuttig zijn om verliezen (absoluut of ten 
opzichte van het budget) groter te maken door toekomstige kosten alvast op de huidige periode te laten drukken als er toch al verliezen zijn. De toekomstige resultaten zullen dan groter zijn en derhalve ook de bonus 42,43 .

Overeenkomsten inzake het verschaffen van vreemd vermogen kunnen bijzondere bepalingen bevatten waardoor de risico's woor de vemogensverschaffers beperkt worden. Hierbij spelen gegevens uil de periodieke verslaggeving en belangrijke rol. Bijvooorbeeld restricties met betrekking tot dividend uitkeringen, inkoop van eigen aandelen, werkkapitaal, fusie, (des)investering, en eventueel nieuw aan te treken vreemd vermogen. Dergelijke voorwaarden zijn bedoeld om de verschaffer van vreemd vermogen bescherming te bieden tegen inbreuken op zijn rechten door de ondernemingsleiding. Perfect is die bescherming echter nooit, omdat de ondememingsleiding kan kiezen uit een verzameling waarderingsprocedures en het is aan te nemen dat zij zich bj deze keuze zall laten leiden door eigen belangen. Deze belangen zuilen ceteris paribus urgenter zijn naarmate de solvabiliteit lager is. Dit is de strekking wan de 'debt hypothesis:

De effecten van beloningscontracten en schuldowereenkomsten werken door in de marktwaarde van het eigen vermogen. Voorzover de keuze van waarderingssystemen vrijwillig is, zal het effect echter niet goed meetbaar zijn, omdat het gering is en er door de vermogensmarkt op wordt geanticipeerd. Stelselwijzigingen die door regelgevende instanties worden opgelegd, zijn gemakkelijker waar te nemen omdat zij minder goed door de markt voorspeld kunnen worden en per bedrijfstak kunnen verschillen.

Lobbyen, onderhandelen, informeren en coalities aangaan brengen kosten en opbrengsten met zich mee. De theorie weronderstelt derhalve dat politici en ambtenaren maatregelen voorstellen en invoeren die voor hen gunstige (her)verdelingseffecten teweeg brengen. De basis voor dil gedrag is de rationaliteit van de individuele belegger/aandeehouder die zich (te) hoge kosten zou moeten getroosten om op de hoogte te raken van de plannen wan de regelgevende overheid en van de werkelijke gang van zaken in de ondememingen. Net als op de vermogensmarkt, zal de kleine man zich als "free rider' gedragen en zujn informatie verwerven 
via de inspanningen van anderen, in casu de regelgevende instanties en de politici ${ }^{44}$ "Gegeven de betrekkelijke onwetendheid: van het publiek, is het voor politici interessant om vooral te letten op "crises" rond ondememingen en naar aanleiding daarvan maatregelen woor te stellen. Exorbitante winsten - wat ook de werkelijke oorzaak - kunnen worden aangegrepen om prijsbeheersing of andere interventies voor to stellen $^{45}$. Ahankelijk van de actuele politieke trend, kan het tegengestelde ook woorkomen: steunverlening bij exorbitante verliezen.

In alle genoemde situaties is het voor de ondernemingsleiding aantrekkelijk om bepaalde waarderingsgrondslagen to kiezen. Ook is het uiteraard voordelig om invloed uit te oefenen op het regelgevingsproces zelf. Dit roept al gauw de gedachte op dat grote ondernemingen meer belang hebben en ook beter in staat zijn dan de kleinere, om winstneming uit te stellen en invloed uit te oefenen. Deze zogenaamde 'size hypothesis" is echter niet cenwoudig te toetsen omdat er ook tegengestelde krachten in het geding zijn. De kans om effectief samen te werken met het politicke apparaat is voor een grote onderneming groter dan voor een kleine. Dit houdt in dat er ook voordelen zijn verbonden aan het groot zijn.

Tot zover de theorie, maar hoe staat het met de empirische resultaten van de "positieve accounting"? Deze zijn nog niet bijster bevredigend, maar er is goede hoop. Eến van de redenen waarom de resultaten tot dusver niet aan de aspiraties voldoen, is gelegen in de veelheid aan gecompliceerde relaties die de theorie bevat. De gangbare econometrische methode wordt daardoor gekoppeld aan minder gangbare vormen van historisch onderzoek. Deze koppeling heeft tijd nodig om zich te ontwikkelen. De 'event study approach' die veelvuldig wordt gehanteerd is lastig, want welke gebeurtenissen dient men in de analyse te betrekken en welke niet? De kennis van historiografische methoden is onder berichygevingsonderzoekers niet erg groot, vitzonderingefi daargelaten ${ }^{46}$. Een ander probleem is de beschikbaarheid van adequate data. Een deel van de variabelen die de theorie als relevant aanwijst is namelijk aan de waarneming onttrokken, omdat zij betrekking hebben op de inhoud van specifieke voorwaarden die zijn neergelegd in contracten waarover partijen doorgaans geen mededelingen doen. De eerste empirische analyses in het kader van de posilieve theorie hadden 
daardoor een te geaggregeerd karakter en moesten met behulp van ceteris paribus clausules overeind gehouden worden.

Geheel in lijn met de positiewe theorie, veronderstellen Zmijevski en Hagerman (1981) dat de keuze van waarderingsregels simultaan plaatsvindt en in het teken staat van én of andere inkomensstrategie van de ondernemingsleiding. Deze strategie ${ }^{47}$ is de afhankelijke variabele in hun model. De werklarende variabelen zijn respectievelijk ondernemingsgrootte, systematisch risico ('bêta'), kapitaalintensiteit, concentratie, winstdeling en solvabiliteit. De empirische resultaten van dit model zijn niet slecht, in aanmerking genomen dat het één van de eerste pogingen is. Ondernemingen blijken inderdaad een geintegreerde 'policy' te kiezen en niet één waarderingsgrondslag per factor. Het model voorspelt goed voor grotere ondernemingen en voor geconcentreerde bedrijfstakken, hetgeen onder andere suggereert dat kleine ondernemingen in niet-geconcentreerde sectoren geen overall policy hebben. Dit onderzoek heeft externe validiteit. In de praktijk gaat het inderdaad om het kiezen van een samenhangend systeem van grondslagen. Aangezien er verschillende effecten kunnen optreden, die elkaar soms neutraliseren en er meerdere belangengroepen en contractpartijen zijn, is de keuze van cen systeem niet eenvoudig, ook in cognitief opzicht. Om dezelfde reden is het ook moeilijk om met sterk geaggregeerde data tot een afgeronde verklaring van dit gedrag te komen 48 .

Watts en Zimmerman (1986) bespreken zeer uitvoerig een viertal studies naar vrijwillige en opgelegde stelselwijzigingen ${ }^{49}$. Het voert te ver deze hier ook te bespreken. Slechts eén ervan zal ik globaal schetsen om te illustreren dat er mogelijkheden zijn het cognitieve onderzoek te combineren met dat van de positieve accounting.

Leftwich (1981) trachtte te verklaren waarom ogenschijnlijk cosmetische stelsel wijzigingen zoveel beroering konden wekken. De APB opinions 16 en 17 - over "business combinations" en "intangible assets' - hebben namelijk geen directe cash-flow effecten terwijl er toch veel commotie over was. Leftwich gebruikt een 'event study'-aanpak waarbij hij 21 gebeurtenissen identificeert in de periode 1968 tot 1972 . Bij negen van deze events constateert hij een abnormale dagelijkse renta- 
biliteit die hij als te verklaren variabele in xijn model opneemt. Leftwich belangrijkste hypothese is dat cen opgelegde stolselwijziging die geen directe cash-flow effecten heef, indirect via de contracten inzake de financiering met vreend vermogen wel effect heef. De betrokken ondernemingen hebben er darom wèl belang bij en zullen overgaan tot lobbyen bij accountants en regelgevende instanties. Ook zal er een effect op de koersontwikkeling zijn, omdat langs deze indirecte weg, de aandeelhouders mede partij zijn. In grote trekken blijken de data deze gedachte te bevestigen, maar er zijn nogal wat problemen rond de statistische performance van het model, dat dus voor verbetering vatbaar is. Wederom blikt dat vele variabelen met clkar in verband stan on aanteiding geven tot multicolliniariteil. Problematisch is ook dat weel variabelen ongeveer hetzelfde verschijnsel meten. De conclusie kan zijn dat dit model op een te hoog niveau van aggregatie wordt getoetst. Lefwich - en met hem de meeste andere positieve accounting onderzoekers - gaat voorbij act het feit dat de betrokken beslissers in het kader wan dit soort ingewikkelde situaties, over zeer geavanceerde cognitieve vaardigheden zouden moeten beschikken om de 'juiste' beslissing te kunnen nemen. Voorzover de theorie niet weerlegd wordt door de feiten, kan men hooguit concluderen dat er een zekere neiging onder de mensen bestaat de problemen aan te pakken op een manier die de theorie beschrijft. De theorie geeft wel aanwijzingen, maar zou niet uitsluitend door middel van geaggregeerde, econometrische methoden getoetst moeten worden ${ }^{50}$. Het ligt zeker ook voor de hand veldonderzock en 'experimental economics" te entameren 51 .

\section{Accountantscontrole}

Accountants mogen in deze beschouwing nit ontbreken. Teveel al was hun werk geisoleerd geraakt wan de beofening wan de bedrijseconomie. De redenen daarvoor zijn misschien trivial en hebben meer met institutionele factoren te maken dan met principiele overwegingen. Accountanis hebben het druk de laatste tijd en om het hoofd boven water te houden, concentreren zij zich liever op fusies, EDP-auditing, nieuwe EG-richlijnen en andere zaken die hun functioneren bedreigen of verbeteren. De vroeger zo sterke relate met de bedriffeconomie 
staat niet meer in het centrum van de belangstelling. Dat kan te maken hebben met het grotendeels verdwijnen van de klassieke, vooral Limpergiaanse bedrijfseconomie. Wat er de laatste jaren aan onderzoekresultaten in de literatuur verschijnt, statt ver weg wan het Limpergiaanse bed en wordt door een deel van het beroep derhalve slecht begrepen. Toch zijn er juist de laatste tijd weer trends in de richting van herstel van de relaties tussen bedrijfseconomie en accountancy. Voornamelijk internationaal, maar ook nationaal. Redenen genoeg om enkele recente ontwikkelingen te schetsen. Een andere reden is dat de onderwerpen die ik in deze rede de revue heb laten passeren, weer keurig bij elkaar komen als we het hebben over de accountantscontrole.

In het functioneren van de accountant moet enerzijds rekening gehouden worden met het positieve berichtgevingsonderzoek en anderzijds met de cognitieve aspecten rond zijn oordeelsvorming. Wie anders heeft zijn beroep gemaakt van 'tekenen die kunnen bedriegen'52. Berichtgeving (accounting) en accountantscontrole (auditing) zijn in de positieve theorie waarin het accent ligt op 'contracting'- en politieke kosten, nauw met elkaar verbonden. De vraag naar berichtgeving is in cerste instantie het gevolg van contracting teneinde agency-kosten te reduceren. Contracten zijn evenwel niet effectief zonder monitoring en controle op naleving. De controle door een accountant is eén van de meest voor de hand liggende en efficiënte manieren om de monitorfunctie te versterken. De contracting-theorie kan behulpzaam zijn bij het verklaren wanneer en in welke mate de professionele hulp wan de accountant gevraagd wordt, vooral als deze hulp niet door wettelijke voorschriften verlangd wordt ${ }^{53}$. Het politieke proces en de wet- en regelgeving zijn belangrijk voor het beroep, omdat de accountant kan optreden als deskundige die de voorschriften voor zijn cliënt interpreteert en zo kan bijdragen aan de waarde van de onderneming. Anderzijds is de regelgeving een belangrijke bron van inkomsten voor de accountant die zich immers verzekerd weet van een (semi-) wettelijke basis voor de afzet van zijn diensten.

De implicaties van de contracting-theorie voor de accountant hebben onder meer betrekking op: (1) competentie, reputatie en onafhankelijkheid; (2) beroepsorganisaties; (3) de structuur van accountantsfirma's en schaalvoordelen; (4) de vraag naar controle in een niet- 
gereguleende omgeving; (5) de invloed wan de politick en de regelgeving 54 .

De competentic van de accountant is gekoppeld aan de warschijnlijkheid dat hij - bij cen bepaalde graad van inspanning - een contractbreuk opspoort, terwijl zijn onathankelijkheid wordt weergegeven door de waarschijnlijkheid dat hij deze wanprestatie inderdaad rapporteert. Dit zal niet altijd geapprecieard worden door de ondememingsleiding die dan ook beschikt over een manier om de accountant schade te berokkenen door een andere accountant te nemen 55 . De accountant zal - in deze theorie - niet iedere contractbreuk melden, maar cen afweging maken. Uiteraard is bij dit alles de reputatie het belangrijkste produktiemiddel van accountants. Onafhankelijkheid wordt bevorderd door reputatie en door beroepsorganisaties die eisen stellen aan opleiding en integriteit van de leden. Samenwerking in maatschappen bevordert de integriteit en de onafhankelijkheid van de accountants en zorgt voor wederzijds toezicht. Naarmate de maatschap groter is, is men minder gevoelig voor cliënten die zich verzetten tegen het melden van ongerechligheden. Tevens wordt zo gemakkelijker een reputatie opgebouwd en gehandhaafd ('merknaam').

De invloed van de politick en de regelgeving op de accountancy is onmiskenbaar. De huidige regelgeving is gebaseerd op de gedachte dat beleggers (en andere belangengroepen) informatie behoeven om hun beslissingen te ondersteunen. Dit heeft twee gevolgen: (1) ook informatie buiten de sfeer van de contracting wordt rele vant geacht; (2) uniforme voorschriften moeten de wergelijkbaarheid van ondememingen bevorderen. Eén en ander verandert de functie van de accountant drastisch: enerzijds minder vraag naar controle uit hoofde van contracten (nalevingscontrole en 'bonding') en anderzijds een ruimer controledomein en meer additionele diensten zoals voorlichting over nieuwe regelgeving, Jobbyen inzake regelgeving, hulp bij skeunaanvragen, etc. Deze additionele diensten bevorderen de sector-specialisatic.

Een tweetal studies illustreren wat de toepassing van de positieve theorie op kan leveren.

DeAngelo's (1982) empirische analyse bevestigde de hypothese dat 
ondernemingen die negatief beinvloed worden door regelwijgiging, eerder van accountant weranderen. De nieuwe accountant zal eerder accoord gaan met de 'conecties' dic de ondememingsleiding wenst aan te brengen om alsnog op een gewenst resultaat uil te komen. $\mathrm{Zij}$ onderzocht daarloe 246 olie-en gasmatschappijen die geconfronteerd werden mel FASB 19 over het activeren wan exploratiekosten 56,57 .

Simunic (1980) onderzocht de hypothese dat Big Eight-kantoren en kartel vomen op de markt voor controle van grote ondernemingen. Daartoe werd een enquête gehouden warin ondememingen werd gevraagd naar de accountantskosten. Verondersteld werd dat de markt van kleine ondernemingen wel en die van grote ondememingen niet competitief zou zijn. Enkele andere variabelen waren het aantal geconsolidecrde dochters, de verhouding buitenlandse activa/totale activa, de verhouding debiteuren/totale activa, en de verhouding netto winst/totale actiwa. De uitkonsten van dit onderzoek tonen aan dat er geen kartel is. Wel zijn de koston van Price Waterhouse hoger dan die van de rest, maar dat blek verbund te houden met een relaticf groter aundeel van die firma in clienten die een groot deel zelf doen met een inteme accountantsdicnst. Price Waterhouse lijk gespecialiseord te zijn in controles bij ondememingen die hun eigen accountantsdienst hebben en dic hoge kwalliteit vragen van de externe accountant. Ook bleek dat de accountantskosten sterk bepaald worden door de complexiteit van de cliént/onderneming. Een plausibel resultad ${ }^{58}$.

Bij de controle van de berichtgeving door de accountant is significantie (materiality) 59 een belangrijk criterium. Fouten zijn alleen interessant als zij groot genoeg zijn, dat wil zeggen, als zij van invloed zijn op de beslissingen in het kader van de berichtgeving, mede gelet op de kosten die gemoeid zijn met de opsporing en de correctie wan de betrokken fouten. De accountant moet daarbij tevens rekening houden met de gebruiker van de informatie. Traditioneel gaat men uí van een standaardgebniker: de rationele outsider. Ook is het gebruikelijk om een onderscheid te maken tussen significantie in het kader van de externe verslaggeving en significantie in het kader van de accountantscontrole. Beide conventies kumnen evenwal misleidend zijn. 
De rationele outsider is een fictie. De rationaliteit van gebruikers van berichtgeving laat veel te wensen over en is divers ook als er niets op aan te merken is. Gebruikers verschillen sterk en zij bevinden zich met de onderneming - in een sociale en politieke context die van beslissende betekenis is voor de beoordeling van de significantie. Hun belangen zijn niet identiek en kunnen botsen. De bedreiging van deze belangen kan per groep verschillen, mede afhankelijk van de contracten die daarover gesloten zijn. Niet zelden bevinden bepaalde belangengroeperingen zich in een toestand van stress, zoals bijwoorbeeld de werknemers ingeval van een mogelijke sluiting of afvloeing. Of de bankfunctionaris die een extra-krediet zou kunnen verlenen maar zich bij wijze van anticipatie voorstelt hoe zijn chef zou reageren als mocht blijken dat de onderneming niet meer te redden is. Stress is trouwens maar ến factor, te denken walt ook aan zaken als het locale belang van een ondememing, de politicke steun die gemobiliseerd kan worden om cen bedrijf op de been te houden, de rol van commissarissen on hun stijl van werken. De rationele accountant zou met al dit soort factoren rekening moeten houden om het juiste niveau van zijn controleinsparning te bepalen 60 .

Dat er twee soorten significantie zouden zijn is op het ecrste gezicht wel plausibel. Immers, bij de externe berichtgeving moet een beoordeling worden gemaakt in het licht wan de normen die wet, gebruik en wetenschap zouden leveren. Gegeven die nomen, zou de accountant een oordeel mocten geven dat consistent is met dat van zijn berocpsgenoten 61 . Bij het maken van een extern verslag moet de ondernemingsleiding bepalen welke informatic-elementen relevant zijn voor de gebruikers. Dat zou dan de 'accounting materiality' zijn. De accountant zou een rekenkundig criterium moeten gebruiken met betrekking tot de fouten in het verslag: de 'auditing materiality". Maar dit onderscheid is kunsimatig en alleen verklaarbaar als de oplossing van een lastig probleem, namelijk het probleem dat accountants bij het afgeven van hun verklaring rekening te houden hebben met de significantie van fouten in hel verslag. Door het probleem te reduceren tot consistentie onder accountants, wordt het onder het kleed geschoven, Door het eens te worden, bijvoorbecld op grond van afspraken over acceptabele afwijkingen, wordt op z'n best een intersubjectief oordeel geveld, geen objectief. In de prakijjk wordt het onderscheid 
Uussen "accounting" en auditing" materiality dan ook niet door iedere accountant gemaakt. Dit blijkt bijvoorbeeld al uit het feit dat de ene grote Nedierlandse accountantsmaatschap significant meer clienten heeft dic weel werk maken van de verstrekking van prospectieve informatie dan de andere. Dat kan aan die clienten liggen, maar dan nog is het geen toevall dat ze een relatieve voorkeur blijken te hebben voor dat ene accountantskantoor.

De beoordeling van significantie is de laatste jaren belangrijker geworden. Enerzijds heeft er meer onderzoek plaatsgevonden natar de subjectieve oordeelsvorming door accountants. Anderzijds zijn de kosten van fouten sterk gestegen. Steeds vaker wordt het beroep geconfronteerd met claims van gebruikers die vam oordeel zijn dat de accountant ten onrechte cen goedkeurende verklaring heeft afgegeven, waardoor zij, schade hebben geleden. Deze kostenstjging maakt het interessant om nader te analyseren hoe de oordeelsworming van de accountant tot stand komt. In het bijzonder wordt daarbij gelet op de inschatting van risico's. Het is duidelijk dat de lwee in deze rede besproken invalshoeken agency theoric en cognitief onderzoek - samenkomen in de analyse van de beoordeling van significantie. De partijen die eventueel schadevergoeding kumen eisen, komen in de agency-theorie expliciet aan bod; hun belangen worden meegenomen in de analyse. Dat de cognitieve benadering in dit geval relevant is, lijdt geen enkele twijfel. "Materiality' en 'audit judgment" zijn aldus nauw verbonden met "accountability". Eigenlijk is er geen beter thema wan praktische importantie als het gaat om de integratie van agency-theorie en human information processing.

De accountantscontrole is vooral zo belangrijk vanwege het feit dat het 'getrouwe beeld" als hoogste criterium geldt voor de beoordeling van de externe verslaggeving. Het voert te ver ook over dat onderwerp hier nog lang uit te weiden. Anderen hebben dat al gedaan en ik kan er op dit moment weing meer aan toevoegen dan dat ik het een nutig en fraa principe vind. Het is nuttig omdat erin tot uitdrukking wordt gebracht dat zelfs wettelike voorschriften slechts begrensde mogeligkhedon hebben en het is fral dat zoiets in een wet verankerd kan worden. Het principe is anderzijds wel verantwoordelijk voor veel problemen in de berichtgeving en de accountantscontrole 62 . Her laat veel numte voor het onderzoken van tekenen die kunnen bedriegen. 


\section{Noten}

1. Soms is het gewenst een ruader onderscheid aan te brengen tussen teikenen, signalen en symbolen, eventueel in samenhang met begrippen als concepties, beelden en modellen. Ackoff en Emery (1972) doen dat als volgt. Het begrip teken ('sign') is thet ruimst: "anything that is a potential producer of a response to something other than itself" (p. 161). Symbolen en signallen zijn tekenen. Een symbool is een teken van een teken (p. 168) en een signaal is gedrag dat door jemand teweeg gebracht wordt als teken vart zijn intenties met betrekking tot het gedrag van anderen (p. 169).

2. Niet alleen accountants women zo hun inkomen, maur ook de financicle joumallistick, inclusief het baanbrekende werk van zelf-benoemde anklagere als Lakeman.

3. Berichtgeving is een Nederlandse wertaling wan 'sccounting', dat is de inteme en exterme, weelal financieel-economuische gegevens-verstrekking en -verwerking door en in organisatives, in het bijzonder ondememingen, en belanghebbende ontwangers van deze gegevers. Traditioneel wordt dit specialisme in Nederland wel aangeduid als 'kosten, waarde en winst' al dan niet voorzien van het voorvoegsel 'leer van de' of het achtervoegsel 'vraagstukken".

4. Ook Kaplan (1984) is wan mening dat berichtgeving een levend' taalsysteem is waar goed naar gekeken dient te worden door onderzoekers, want anders onigaan hun de weranderingen die voondurend platsvinden.

5. Deze 'storingen' in de communicatie worden door Bimberg et al. (1983) onderscheiden.

6. $\operatorname{Lev}(1974)$

7. Volgens Langer (1975) zijn mensen vaak gemotiveerd om hun omgeving te beheersen onder omstandigheden die zich daantoe niet lenen. Dit houdt verband met het feit dat toevall en vaardigheid in de praktijk (non-experimentele siluaties) moeilijk te scheiden zijn: "there is an element of chance in every skill situation and an element of skill in allmost every chance situation". Zie ook Hogarth en Makridakis (1981) die het verschijnsel 'illusion of control' toepassen op planning en derhalwe spreken van een 'planning fallacy' die planners dikwijls het gevoel geeft het zelfgemaakte plan te kunnen vitwoeren zonder gecontroleerd te hebbun of hun plannen wellicht woorkomen wit 'wishful thinking'. In toepassingen wan de attributietheorit komt hier nog bij dat welen geneigd zijn een goede afloop aan zichzelf te wijten en een slechte afloop aan anderen of ala de omstandigheden. Voor een overzicht van de attributietheorie zie Hewsione (1983). Zie ook noot 23.

8. Zie Janis en Mann (1977) over de rol wan commitment en stress in de besluitworming.

9. Hoogendoom (1987) 
10. Zie Bouma $(1966)$

11. Zie Bouma (1968) en Burger (1967)

12. Zie onder andere Schreuder en Klaassen (1982); Schreuder en Volmer (1987); Faas (1986) en (1987)

13. Zie bijwoorbeeld Hogarh (1980) en Feenstra en Van de Poel (1985)

14. Zie bijwoorbeeld Homgrem en Foster (1987)

15. Het aurdige van probleemgestund onderwijs - zoalls dat a an de Rijksuniversiteit Lumburg toegepast wordit - is dat zulke reacties al wer woor het afstuderen gehoord kunnen worden. De docent krijgt daardoor de gelegenheid tijdig corrigerende matatregelen te nemen, bijvoorbeeld door het raadsellachtige verschijnsel onder de aandacht wan de (keine) groep te houden en de studenten zodoende aan te sporen verklaringen te zoeken.

16. Zie Zimmeman (1979)

17. Elders heb ik al een begin gemaakt met deze integratie zie Wan de Poel (1986)

18. Zie Ansari en Euske (1987)

19. Bouma (1982 en 1985)

20. Douma (1985 en 1987); Schreuder (1985): Hendrikse en Schreuder (1987) en Barkema en Dourna (1984)

21. Dit is het antwoord van Alchian en Demsetz (1972)

22. Rir bestatan in dit opzicht interessante verschillen. Toen Coase in 1937 zijn later beroemd geworden anikel schreef, waren het wooral de ideeen wan Knight (1921) die opgang maakten. Volgens Knight vormt de anwezigheid wan 'echte: onzekertheid de reden voor het bestaan van ondememers wier beloning bestat uit 'residual claims'. Zij specialiseren zich in het nemen van risico's op grond van thun besluitvaardigheid, kennis en het vermogen vooruit te zien gepard aan innerlijke en viterlijke owertaiging. Geen gekke gedachte en nog altijd populair, miaur volgens Coase er helemaal maast. Mensen die de genioemde talenten hebben behoven niet werkelijk leiding to geven. Hun deskundigheid kan net zo goed via markttransacties geleverd worden. In dar geval wordt het inkomen wan de deskundige niet per se gekoppeld anen de onzekené aitkomsten van de ondememing. Coase postulett een dynamisch evenwicht assen transacuickosten op de markt en coördinatiekosten in de ondememing ter verklaring van hel bestasan van ondememingen wan een bepaallde grootte. Dit aitgangspunt kan op tweeërlei wijze worden tiitgewerkt. Alchian en Demseiz (1972) richten thun analyse op de agency-kosten die verband houden met "teamproduktie" en "shirking". Doot Williams on (1975) en Williamson et al. (1975) wordt de analyse gericht op thet arbeidscontract en komt het accent te liggen op de 'idiosyneratic exchange' oftewel 
job-relatod skills" en de inteme arbeidsmarkt die de werklaring womt wain "gezagg".

23. De anributietheorie probeen uit te vissen hoe mensem de hen omuingende 'wereld" verklaren. Er zijn vele varianten van depe theorie (ze Hewstone, 1983), Een ved gebruikt model * afkomstig van Kelley (1967) - postuleent dat mensen een soort ANOVA-schema hamteren wasbij zij op nazeve wijze de van J.S. Mill afk on sige 'method of difference hanteren. Een effec wordt aldus an een condilie toegenend als de conditie wargenomen word, terwijl dat effect niet wordt waargenoment als de conditie af wezig is. In Kelley's model worden drie condities onderscheiden: (1) consistentie: infornatie ower het gedrag van hat te beoordelen object in hef verleden; (2) consensus: infomatie over het gedrag van soongelijke objecten in dezelfde siluaties; (3) distinctie: intormate over het gedrag van het objed in andere situaties.

24. Het gedragsmodel wan Fishbein en Ajzen (1975) en het daarvan afgeleide model van Van Raaij en Verhallen (1983) zijn goede kandidaten voor dergelijk onderzoek. In het latste model worden kosten en balien afgewogen, maar nict per sé volgens een a priori calculatie-schema. Zie Van Raaij (1987).

25. Feenstra en Van de Poel (1985)

26. Klant (1972) onderscheidt een 'rationalistisch' en een 'empirisch' apriorisme. Bij de eerste methode wordi veclal gebruik gemaakt wan wiskundige en logische analyse, terwijl de premissen meestal slechts getoetst zijn an intunicve beoordeling door de theoreticus. Het "Limpergianisme" dat de klassicke bedrijfseconomie domineerde is hier een vootbeeld wan. Het "empirische' apriorisme toetst de premissen wèl empirisch er maakt veclal gebruik van numerieke analyse voor de afleiding van conclusies. De klassicke Rotterdamse aanpak vertoont hier trekjes wan " matar ook de moderne toepassing van simulatic. technieken, gevoeligheidsanalyse en scenario"s horen tot deze categorie.

27. Enkele voorbeelden van 'principal-agent' onderzock zijn Harris en Raviv (1979), Holmstrom (1979), Shavell (1979).

28. De naamgeving kan enigszins verwarrend zijn ondat in deze methode zowel deductic als inductie gebnilkt worden. Het proces van hypothesevorming wordt als inductief opgeval omdat er noch een betrouwbare theorie, noch een hetrou wbarc afleidingprocedure woor hypothesen wordt werondersteld. Dit in tegenstelling tor de axiomatische methode. Er zijin verschillende variariven in dit model. A ari de ene kant is er een aanpak waarbij steeds een gocd geformuleerde en nog niet verworpen theorie als checkpunt fungert. Deze warierit grenst als het ware alan de axiomatische methode. Aan de andere kant is een benadering denkbar dis geen functie heeft voot een theorie, mas die telkens opriteuw begint met observatics. Dit lastste is echter strijdig met de gedachte dat wetenschap een proces is wan systematisch opbouwen van kennis. Er is dus in ellk geval een zekere theoric. vorming van waaruit de (nieuwe) obserwatie gestant wordt an wezig. De warianten die binnen de deductief hypothetische methode mogelijk tijn, werschillen derhalwe in de mate waarin zij gebruik maken wan reds geacentecthe kenuis. 
29. Enkele woorbelden van: 'positief' agency onderwek zijn Achian ex Demsetx (1972), Jensen en Meckling (1976), Fana en Jenten (1983a en 1983b), Jersen $(1983 \%$.

30. Deze aanpak die ook wel 'ontwenpende' benadering of 'design approach' word genoemd en die grote overeenkonsten verioont met de "prariciperende observatie" is onder meer ic virden bij Achoff (1981). Bouma (1982) en Bronsema (1988). Als methode wan wetenschapreliy onderzoek heef deze anpak de wolgende woordelen: (1) efficiênte verameling van moeilijk te verkrijgen data; (2) exploratie van nieuwe verschijnselen in de praktigk (zie ook Kaplan, 1984 en Johnson en Kaplan, 1987), (3) toepassingsgericht: analyse en consuhteren gaan hand in hand; (4) aanvolen van moeilijh te begrijpen aspecten van de werkelijkcheid ("Verstehen").

31. Niet-restricticve disciglines gaan er wolgens $V_{a n}$ Rossurn (1985) - in navolging wan Pawtin (1968) - wan ail dat de complexiteit wan hun objecten niet via een reatrictieve fedenering butten beschouwing mag worden gehouden; het zijm wetenschappen die hun object nict wersimpelen. $Z$ ij lenen daarom veel wuldig van andere disciplines, watar hanteren hun eigen invalshoek (paradigma of theorie) als sturing smiddel. Schreider (1985) - Van Rossum citerend - wijst er verder op dat de prasitieves agency-theorie niet en de principal/agent literaturu wel restrictief is. Een woorbeld wan een niet-restrictieve toepassing van de agency-theorie is. Horngren $(1986)$.

32. De selectie vaft standaarden en nomen in de budgettering werd voor Argyris (1952) gezien als trivial. Stedry (1960) en Hof stede (1967) bevestigden thama de stelling dat motivatie op gecompliceedde wijze samenhangt met de hoogte wan nomen. Mensen accepteren nonmen niet 20 masr en zil reageren er niek 'mechanistisch' op als het budget eenrnal is yastgesteld en het moet worden uitgevord. Hopwood's (1973) bewinding was dat vitwoerders terdege rekening houden met de persoonlijkheid of "stij]" van hun chefs. Hebben de latatsten een 'budget constrained style' dan is er bovendien eern grotere kans dat hun ondergeschikten knoeien met de rapportage. Verder zijn er aanwijzingen dat rutsfunctics onder invloed stan wan subjectief bepalde gevoelens van 'winst' of 'verties' ten upzichte van éen of ander aspiralieniveau. De risicolhouding voor 'wirsten' is in weel gewallen anders dan veor "veriiezen": risico-avers voor winst en het tegendeel voor vertiezen. Gezien de fijmzirnigheid warmee vele agency-theoratici knutselen an nutsfuncties, komt de 'prospeet theory' die deze aspecten omschrift (zie Kahneman en Tversky, 1979, en Van de Poel, 1986 voor een toepassing op het verrein van de budgettering) wel in wanmerking toegepast te worden in een agency-onderzoek. Een aunzat daartioe is gegeven door Uecker el ad. (1985).

\section{Anthony (1983)}

34. Zouls bijwoorbeld blijkt in het geval van de conclusies wan de commissie Van der Grinten inzake beschermingsclasusules. Het rappont van die commissie is sterk juridisch en ziet dertalye weinig bezwanen tegen beschermingsclausule g. De teneur is het mag, dus het kan'. Het beursbestuur had evenwel het gevoel - en terecht nuar mijn smakk - dat het in Nederland wellicht iets te ver éérn kant, namelijk die 
wan het management, op was gegan. Inderdata moet nuem constateren dal argurnenten uit de hoek van de market for oontrol" wiet voorkomen in het rapport.

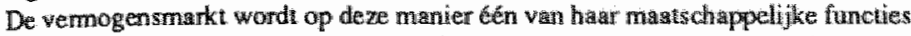

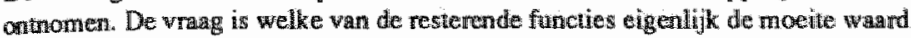
zujp, althans maatschappelijk gezien. De wrag is ook of er andere "lichamen' zin die deze werwakte functie ovememen. Waschijnlijk niek Mar misschien past de huidige sicuatie beter bij de aloude regententraditie te orment.

35. Al is ar dankzij de regelgeving wel een werschil in observerbastheid voor de geinteresseerde outsider. De interne spelregels van organisaties zijin niet wo genakkeligk was te nennen als de externe was deze door de wet bepald worden. Daardoor wornt de unifomening die door de regelgeving is gerealiserd een gunstige conditie woor het onderzoek: grotere vergelijkbatheid in de verslagn: geving leidt tot grotere stekproeven an betere mogelikkheden voor statistische analyse. Dat werklaan misscthien waram onderzoekers 20 weinig bezwat maken tegen de regelgeving.

36. Watus en Zimmenari (1986)

37. De economische benadering van de berichtgeving is noch beschrijvend - al doet thet predikat 'positief' dit vermoeden - noch normtief. Berichtgewing wordt opgevat als gedrag dat wellicht re verklaren is. De auhangers wan deze benadering

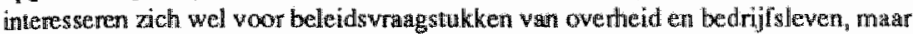
zij vinden dat hun bijdrage beter op getoetste verklaringen kan benusten dan op het leveren wan rechtvarardigingen voor deze of gene botrokkene (Watls en Zimmeman, 1979). Ower de methodologische standpunten wan deze theorie wordt weel gediscussieerd; zij zijn omstreden; zie bijvoorbeeld Christenson (1984); Whitungton (1987) en Van de Poel en Tempelaar (1987). De critici proberen gaten te schieten in de bewering dat de theore wardewrij is. Dat is zij niet.

38. Zie Majioor en Bollen (1987) en Majoor (1988), alsmede Bak (1983)

39. Leftwich (1980)

40. Dit begrip is afkomstig van Akerlof (1970) en in de betichtgevingshiteratuur onder andere gebruikt door Gonedes er al. (1976)

41. Werrecthin (1982)

42. Healy (1985)

43. De manter om dit te doen is niet zo zeer de manipulatie van afschrijuingen, matr de wasustelling van woorzleningen en reserwes. Cien interesgant probleem daarbij is de wrag hoe de "bowuss-plan' hypothese zich verhond tot de "smool hing" hypothese die inhoudl dat de leiding trach de fuctuaties in resultater (voord in rentabiliteit) te beperken. Indien het borus plan geen ondergrens zou hebbem, zou smoothing" natar de bovengrens plausibel zijn. Is er wel cen ondergrens, dan wis de bonusplank" hypothese niet conststent mat de "smowhing" hypothese. Zie voor een overzich van de "smoothing"-literatwur Hoogendoom (1985). 
44. Hat werchil mot de werwogensmarkt is cehter dat de mortor-kosten in de politiok groter ajn dan op de vemogensmartht. Dit wordt mede veroorzalkt door het

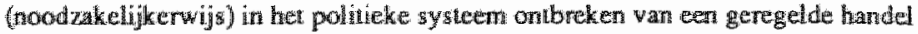

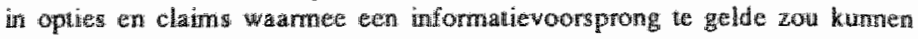

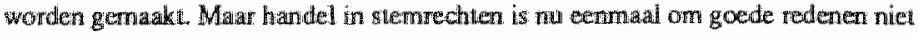
toegegutarim

45. Dat het dawbij wat gaat om procentuele sijgingen van wingten wen opzichte van een alonomal. lage winsu iri de vorige periode, ontgat het putbliek niet zelden. dem typisteh gexall van 'framing' zoals beschreven in de 'prospect heory". Zue ook 29.

46. Zise Merino at all. (1,987)

47. Zmijeviki en Hagennarn (1981) analyseerder strategieèn die samengesteld $z$ äjn ait warderingsregels met betrekking tot (1) investeringsaftrek; (2) afschrijwingem;

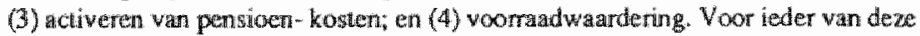
factoren werd exer voordelige en een nadelige invulling ondarscheiden.

48. Op een punt werd een verbetering genealis eerd door Healy (1985) door expliciet rekening te houden met de specifieke detais van ieder bonusplan. Aharkelijk wan onder en bovengremzen in het bonusplan, is het interesant woor het managentent om te schuiven net resuluaten. Healy concentrerde zich derhalve op het verschil wussen de pericteresultaten zoals omschreven in het contract en de cash flow wil hoofde van de bedriffswoering (dit werschil heet 'net accruals") Verdere verbeteringen liggen in het verschet, bijvoorbedd door niet an te nemen dal de bonus bepaald wordt door en mechanistische toepassang van de in het contract opgenomen formules. Dit laatsite zou overigens nie: kunnen zonder rekening te houden met cognitieve aspecten nond de prestatiemeting en -beloning. Het brengl de analyse zaer dicht in de buurt van de budgettering.

49. Dit bet nef het onderzok wan Leftwich (1981) over consolidatiemethoden en APB Opinion 16 (business combinations") en APB 17 ('inlangible assets'), her onder. zoek wan Collins et all. (1981) naar HASB 19 over hel verbod van de full-cost methode baj tref activeren van exploratiekosten van olie en gasmatschappijen, de studie van Lys (1984) over hetzelfde thema, en Holthasen (1981) over de overg ang van versnelde op rechulijige afschrijuing.

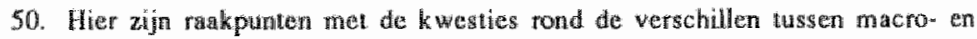

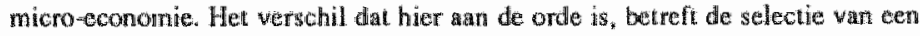

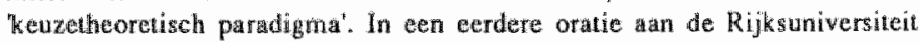
Limburg is hier neds uitgebreid over gexproken (Muysken, 1985). Voonalsnog helo ik dowir nirets an toe te vaegen.

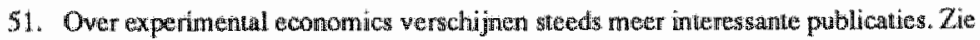
onder andere Uncker al (1985).

52. Het gaat in dil verband uhtsilnitend om de controlerende taak wan de acoountant en niet om de adrigenende functies, althans voorzover deze niel betrekking hebben op 
de keuze varn procedures yoor waandering en presentatie.

53. Er zijn in het kader van de positieve theorie enkcelle interessante hiskorische sudies werricht om te achterhaten wat de vrasg naar accountants is in een ongereguleorde angeving. Chow (1982) bijvoorbeld verklarde de selectie van accountants door ondememingen aan de hand van data bit 1926. Grotere ondememingen blektan vaker en intensiever te worden gecontroleerd dan kleinere omdst (1) hun maxagers relatief minder dechemen in het eigen vermogen en dus eerder in verleiding komen zich te verrijken ten koste van asndeelhouders en (2) de controldkosten per geldeentheid omzet afneemt (er zijn vaste accountantskosten, start-up kosten, etc.). ook bleck dat naarmate de ondememing meer met vreend wernogen is gefinancierd, er meer controle zal zijn. Dit latste effect word wersterkt door het antal voorwararden dal opgenomen is in de schutdowereenkomsten.

54. Watis en Zinneman (1986)

55. DeAngelo (1981) veronderstelt dat de eerste controle-opdracht wordt witgevoerd tegen een prijs die onder de kostprijs ligt "maar dat voor iedere volgende controle een quasi-vent geincasseerd wordt. Wanneer de relatie verbroken wordt, verbeunt de accountant deze cliënt-specifieke quasi-rent.

56. Zie noot 51.

57. Watts en Zimmeman (1986) onderzochten het lobbyen doot accountants inzake woorgesfelde wijzigingen in de regelgeving. Zij veronderstelden dat het lobbyen door accountants afhange van de belangen van hun cliënten. Hiervoor zijn lwee argumenten: (1) lobbyen is een vorm van dienstwerlening; (2) de beloning van de accountmat is (mede) afhankelijk wan de marktwaarde wan de cliëni/ondememing. Accountant en cliënt hebben echter ook strijdige belangten: meer controle-abe id uit hoofde van nieuwe regelgeving is woor de een voordelig cn woor de ander nies. De positie van de accountant werd geacht afhankelijk te zijn wan het effect van de procedure op (1) de marktwaarde van de client; (2) de verzameling toegestane waarderingsregels; (3) de eventuele extra- accountantscontrole. De positie van de cliën/manager werd gexien als een functie van het effect op de mark!waarde van de ondemerning en de beloning van de manager. De statistische resultaten bevestigen de hypothesen. Ook de oordelen van de clënten ondersteunen de hypothesen: de weerstand tegen voorstellen is het grootst als de effecten op het contracting proces bet grootst zijn.

58. Fr is enig Nederlands onderzoek gedaan naar de kosten wan de accountantacontrole. Zie Bak et all. (1985) en Dekker en Largendijk (1986).

59. Over het thema materiality is veel geschreven. Ben gocd overzicht is dat wan Leslie (1985). Samenvatuingen wan thet onderzoek teruake zijn gegeven door Gwilliam (1987) en Joyce en Libby (1982).

60. De rationaliteit van de accountant is onderwerp wan uitvoerige studies. De uitkomsten wan dit soort onderzoek zijn evenwel niet eenduidig. 20 blijken accountants niet beter re kinnen oordelen in relatief eenwoudige situaties watan 
wayschijnijitheden moeten worden gecombineerd (evenals andere metnsen hanteren accountanis in onwoldoende mate hel theorema van Bayes). Zit onder andere Joyce en Biddle (1981), Waller en Felix (1984a) en (1987), Holt (1987). Ervaring blijkt zelfs vaiak een belemmering te zijn bij het correct inschatten van waarschijnijhbeden. In gecompliceertere doch meer realistische gevallen blijken ervaren accountants het echter beter te doen, zo blijkt uit een studidie van Abdolmohammadi en Wright (1987). Het zall de eerste keer niet zijn dat de experimenten die oorspronkelijk door psychologen zijn toegepast op leken in eenvoudige laboratorium-situaties, niet blijken op te gaan woor deskundigen in hun eigen orrigeving (zie ook Van de Poell, 1986). Veel 'audit judgment" onderzoek raakt slechts de "buitenkiant' vian de bevlissingen. Verder onderzoek naar de 'bimerikant' is geboden, vooral met behulp wan protocol-analyses teneinde te beschrijven hoe de cognitieve processen in hun werk gaan. Het model van Gibbins (1981) en dat van Waller en Felix (1984b) kunen daarbij als vitgangspuriten dienen. Zie verder Van de Poel en Vaassen (1988).

61. Zie bijw. Wolk et al. (1984).

62. Enkele problemen wan 'true and fair zijn (1) de invoering ervan in landen met een andere cultuur dan die in Nederland en het Vereraigd Koninkrijk (zie Van der Tas, 1987 alsmede Koene en Van de Poel, 1988); (2) het relatief grote gewicht van de rechuspratk woor het ontwikkelen wan nomen; (3) cen relatief grote onzekerteid bij de accountantscontrole, mede in het licht van de aansprakelijkheidsrisico's. 


\section{Literanuar}

Abdotmohammadi, M. Wright, A., An tamination of the Bffects of Experitence and Task Complexity on Audi Judgments, Accouning Rewien 62, No, 1, januari, 1987

Ackoff, RL., Entery, F.E. On Purposeful Systems, Aldine-Atherton, Ohicago, 1972 Ackoff, R.L.. The Art and Science of Mess Management, Interfaces 11. No. 1,1981

Akeriof, G.A., The Market for 'Lemons': Quality Uncertainty' and the Market Mechanism, Quarteriby Jownal of Economics 84, augustus, 1970

Alchian, A.A., Demsel $z_{*}$ H., Production, Information Cost and Economic Organization, American Economic Review 62, 1972

Ansari, S.L., Euske, K.J., Rational, Rationalizing, and Reifying Uses of Accounting Dats, Accounting, Organizations and Society 12, No. 6, 1987

Anthory, R.N. Tiell it Like It Was: A Conceptual Framewor for financial Accowning, Richard D. Inwin, Inc. Homewoood, 1983

Argyris, C., The Impact of Budgets on People, Coninollership Foundation, 1952

Bak, G.G.M., Dekker, H.C., Langendijk, H.P.A.J., (red.), Beheersing van (kosten wan) accountanscontrole, Kluwer/NTVE/FINEM, 1935

Bak, G.G.M., Informatieverstrekking in de weede golf, TWVS, nr. $83 / 6,1983$

Barkema, H.G., Douma, S.W., Agency-theorie en de concemtolding als intemediair, in Wan de Bergh, W.M., van der Mevien, J., Ruizendagl, G.J.., Verhaegen, P.H.A.M. (red.), Financiering en Belegging, Stand wan zaken anno 1984, Erasmus Universiteit, Rotterdim, 1984.

Besver, W.H., Clarke, R., Wright, W., The Association Between Unsystematic Security Returns and the Magnitwide of Lamings Forecast Errors, Sowroul of Accouning Research 17, herfist, 1979

Beaver, W.H. Lambert, R., Morse, D., The Information Content of Security Prices, Jourmal of Accouning and Ecowomics 2, maar, 1980

Bimberg, J.G., Turopolec, L., Young. S.M., The Organizational Context of Accounting, Accounting, Organizations and Society 8, No. 2/3, 1983

Bouma, J.L., Ondernemingsdoel en winst, Stenfer Kroese, Leiden, 1966

Bouma, J.L., Commentaar op het prae-3dvies van Burgert, Accoumbantsdag 1967, De Accowntani 74, no 9, 1968

Bouma, J.L. Leerboek der bedriffseconomie, deel 1, Delwel, Wassenaar, 1982

Bouma, J.L., Geld kent geen grenzen, in Muysken, J., Schreuder, H, red, Economische wetenschappen: wenheid in verscheidenheid, Van Gorcum. Assen/Mastricht, 1985

Bromwich, M., Hopwood, A.G., (eds.), Reseanch and current issues in mamagement accoututing, Pitman, London, 1986

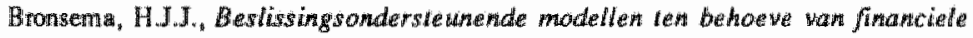
planing en beleggingmanagement: interactie en onmerp dissertatie Rijksuniversiteit Groningen, $198 \%$

Burgent, R. Bedrijfseconomisch aarvaandbare grondslagen woor de gepobliceerde jasmekening, De Accoutiant, septermber 1967

Chow, C.W. The Demand for Extemal Auditing: Size, Debl and Ownership Influences, Accowing Review 57, aprill, 1982

Christerson, $\mathrm{C}$, The Methodology of Positive Accounting, Accomning Review, jantas ${ }^{*}, 1984$

Coase, R. The Nature of the Firm, Ecomomica 4,1937 
Collins, D. W , Rozef, M. Dhaliwal, D. The Economic Deteminants of the Mather Reaction to Hroposed Mandstory Acconating Changes in the Oull and Gas Indusity:

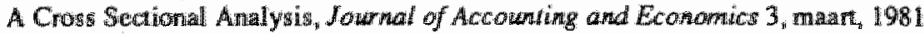

Commisaje Beschemingsconstmcties, Rapporl aan het Bestuur van de Vereniging wor de Effectenhandel (Commitiste Var der Ginten), 1987

De.Angelo, LE, Aadior Independence, "Low Balling", and Disclosure Regulation, Jowrul of Accounting and Economics 3, augustus, 1981

Dekker, H.C., Langendijk, H.P.A.J., De beheersing van de (kosten van) accountantscontrole in Nederland Madudad woor Accountancy en Bedriffshishowdkwide, $60 \mathrm{No}, 8$, september, 1986

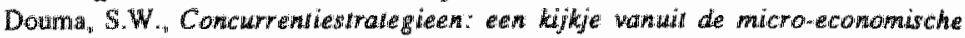
theorie, Open UniversiteidSamsom vilgevinj, 1985

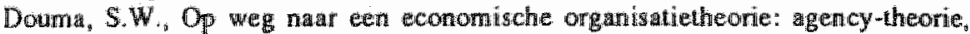
Masulblad voor Acicowntancy en Bedrifs hus houdkunde 61, No 11, november 1987

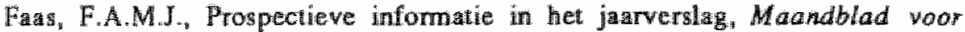
Accountancy en Bedriff huishoudkunde, 60 , No. 8, september, 1986

Fas, F.A.M.J., Prognoses en andere toekomstgerichte informatie in her yarverslag. Finarcied Managument, 7 , Wo. 1, febnari, 1987, pp. 5-16

Fama, E. Jensen, M.C. Separation of Ownership from Control Joural of Law and Ecomomics: 26, $1983(\mathrm{a})$

Fama, E.F., Jensen, M.C., Agency Problems and Residual Claims, Jow mat of Law and Eronomics, $26,1983(\mathrm{~b})$

Fecnstra, D.W., Poel, J.H.R. van de, Bedriffeconomie, Melhodologie en

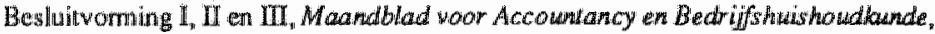
jarnuari, februar, matar, 1985

Fuenstra, D.W., Oordeelsworming rond de externe berichtgewing, Wolters-Noorthoff, Groningen, 1985

Fishbein, M., Ajzen, I., Belief, Anitude, Intention and Behawior: An Intraduction to Theory and Rescarch, Addison.Wesley, Reading, 1975

Gibbins, M. Propositions about the Psychology of Professional Judgment in Public Accounting, Journal of Accouming Research 22, No. 1, Spring, 1984

Gonedes, N, Dopuch, N, Penman, S.H., Disclosure Rules, Infomation-Production, and Capital Markes Equilibrium: The Case of Forecast Disclosure Rules, Jourwal of Accourting Restearch 14, Spring, 1976

Gwilliam, D.R., A Survey of Auditing Regearch, The Institute of Chartered Accountants in England and wales, Prentice-Hall International, London, 1987

Hartis, M., Raviv, A., Some Results on Incentive Contracts with Applications to Fucation and Employment, Health Insurance and Law Enforcement, Ametican Econowitc Rewew 68, 1978

Hendrikse, G.W.J, Sichrewder, H., Fconomische organisatietheoriter, Economisch

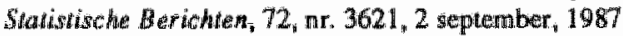

Hewstone, M., ed., Anribution Theary" Social and Funetional Extenstom, Basil Black will, Oxford, 1983

Hoganth, R.M. Judgment and Choice, John Wiley \& Sons, New York, 1980 Hogarth, R.M., Makridakis, S, The Value of Decision Making in a Complex Environment: An Expenimet Approach, Mandgenen Science 27, 1981

Hoftede, OH. The Game of Budger Confrol, Van Gorcum, Assen, 1967

Hofstede, G.H., Cullure's Confequences, Sage Publications, Beverly Hills, 1982

Holstinom, B., Moral Hazard and Observability, Bell Jowrnal of Econowics 26,1979 
Holt, D.L, Audiors and Base Rates Revisited, Accouning, Organizations and Socity 12, No. 6, 1987

Holthansen, R.W. Evidence on the Effect of Bond Cowenants and Management. Compensation Contracts on the Choice of Accounting Techniques: The Case of the Depreciation Swich-Back, Jownal of Accowating and Econowics 3, maat, 1981

Hoogendoom, MN. Het creatieve jaarrekeningbeleid van RSV, Pacioli Joumal, november, 1987

Hoogendoorn, M.N., Income Smoothing. Paper presented at the Eighth Arnual Congress of the European Accounting Association, Brussel, 1985

Hopwood, A.G. An Accounting System and Human Behaviow, Saxon House, London, 1973

Horgren "C.T. Foster, G., Cas Accounting: A Mamagerial Emphasis, Sixu Ldition, Prentice-Hall Intemational, Inc., London, 1987

Horngren, C.T., Cost and management mocounting: yesterday and loday, in Bromwich, M. Hopwood, A.G., (eds.), Research and current issues in managemenil accotaningy. Pitman, London, 1986

Janis, I.L., Mann, L. Decusion Making: A Psychological Analysis of Conftict, Choice, and Commiment, The Free Press, New York, 1977

Jensen, M.C., Meckling. W.H., Theory of the Firm: Behavior, Agency Cost and Ownership Structure, Jourral of Financial Economics 3, 1976

Jensen, M.C., Organizations Theory and Methodology, Accowning Review 58, 1983 Johnson, H.T., Kaplan, R.S., Relevance Lost: The Rise and Fall of Management Accounting, Harvard Business School Press, Boston, 1987

Joyce, E.J., Biddle, G.C., Are Auditors' Judgments Sufficiently Regressive?, Journal of Accourting Research, auturm, 1981

Joyce, E.J., Libby, R., Behawional Studies of Auditing Decision Making, Joumal of Accounting Literaiure 1, 1982

Kahneman, D., Tversky, A., Prospect Theory: an analysis off decision under risk, Econometrica 47, No. 2, 1979

Kaplan, R.S., The Evolution of Management Accounting, Accounting Review 59, No. 3, 1984

Kelley, H.H., Attribution theory in social psychology, in D. Levine (ed.), Nebraskat symposium on motivation, Universiry of Nebraska Press, Lincolm, 1967

Klant, JJ., Spelregehs woor economen, Stenfert Kroese, Leiden, 1972

Knight, F, Risk, Uncertainty, and Profit, Houghton Mifflin Co, New York, 1921

Koeme, B., Poel, J.H.R. van de, Eunnological asperts of accounting regulation, Working Paper, Rijksuniwersiteit Lumburg, Maastricht, 1988 (te verschijnen)

Langer, E.J., The illusion of control, in Kahneman, D., Slovic, P., Tversky, A., (eds.), Judgment under uncertainty: Heuristics and biasss, Cambridge University Press, Cambridge, 1982

Leftwich, $R$., Evidence on the Impact of Mandatory Changes in Accounting Principles on Corporate Loan Agreements, Jow mal of Accowaing and Economics 3, masar, 1981

Leslie, D. A., Materiality: The Concept and its Application to Auditing, The Canadian Insticute of Chartered Acocuntaniss, 1985

Lev, B., Finaricial Shatemeni Analysis: a new approach, Prentice-Hall, Englewood Cliffs, 1974

Lys, T., Mandated Accounting Changes and Debt Covenants: The Case of Oil and Gas Accounting, Journal of Accounting and Economics: 6, april, 1984 


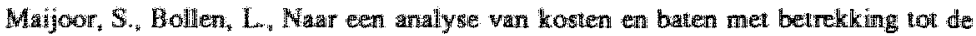
anpasingswat vierde richlijin, Working Paper, WP $87-013$, Rijksuniversiteit Limiburg. Maasinchi, 1987

Maijowr, $\$_{*}$, On the desirability of finamcial reponting rules: the case of The Netherlands, Reseanch Memorandum, Rijksuniversiteit Limburg, Maastrich, 1988 (te verschifiven)

Merino, B.D., Koch, B.S., MacRitchie, K.L., Historical Analysis - A Diagnostic Tool for "Ewents" studies.: The mpact of the Securities Act of 1933, Accounting Rewew 58, No.4, 1987

Moxriand, P. W. Zeggenschap, fisico en de verdeling der toegrvogde waarde, Stenfert Kinoese, Leident 1982

Muysken, I, Hoe algemen is de algemene economie?. Van Gorcum, Assen/Maastrich, 1985; ook in Muysken en Schreuder (1985)

Muysiken, J. Schreuder, H. red. Ecomomische wetenschappen: eenheid is wersctielde nheid?, Wan Gorcum, Assen/Matristrich, 1985

Poe $\mathrm{I}_{\mathrm{H}}$ I.H.R. Wan de, Judgment and Control: Individual and Organizational Aspectss of Purfomance Evaluation, Wolmers-Noondhoff, Groningen, 1986

Poel. I.H.R. van de, Tempelagr, F.M., On the Applicability of Positive Agency "Theory. Research Memorandum Rijksuniversiteit Limburg. Masitrich, 1987

Poel, I.H.R. wan de, Wassen, E., Audit Judgment Research, Working Paper, Rajkuniversiteit Limburg, 1988 (te verschijnen)

Raaji. W.F. Wan, Kosten en baten op de grens van economie en psychologie, in Keizer, P.K., en Soeters, I., (red:), Economie, sociologie en psychalogie: visies op integratu, Vari Gorcini, Asseru/Maastricht, 1987

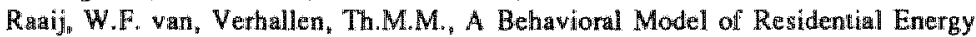
Use, Jownal of Economic Psychalogy, 3, 1983

Rossum, W van, De economie als niet-restrictieve discipline, in Muysken, $J$, Schreader, H., Economische wetenshoppen: eenheid in werscheidenheid?, Van Gorcum, Asgen/Mastricht, 1985

Schreuder, H., Klaassen, J., De voorspelbaarheid van omzelten en winsten, Stenfert Kroese, Leiden, 1982

Schteuder ${ }_{1}$ H. , Volmer, F., Prognoses in het jaarverslag, in E. van der Wolk, Groot Vademecum van de Directeur en Bestuurder De Toons/Van der Wolk Publicaties Laren, 1987, pp. 9.32.01-12

Schreuder, H. Economic theories of organization: An overview and assessment of some recent devellopment: Research Memorandum 85-007, Rijksuniversiteit Limburg, 1985

Schreuder, H. Ecowowie(ew) bedirifen, Van Gorcum, Assen/Mastricht, 1985

Shavell, $S_{., 1}$ Risk sharing and inceintives in the principal and agent relationship, Bell Jownal of Economicis 10, Mo. 1, 1979

Stwodry, A.C. Dudgat Control and Cost Behavor, Prentice Hall, Englewood Clifis, 1960

Tas, L. G. wan der, Jmplementate wan "a true and fair view" in Duitsland (1) en (2)

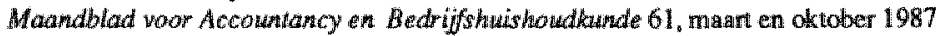

Uecker, W., Schepanski, A., Shin, J., Toward a Positive Theory of Information Evaluation: Relevant Tests of Competing Models in a Principal-Agency Setting. Acconuning Revien 60, No. 3, 1985

Verrechia, R.E., The Use of Mathematical Models in Financial Accounting, Studies on Current Reserah Methodologies in Accounting: A Critical Evalwation, supple- 
ment to Vol. 20 of Journat of Accounting Research, 1982

Waller, W.S., Felix, W.L. The Effects of lincomplete Ontoome Feedbuck on Awditor" Self-Perception of Judgment Ability, Accounting Revien, oktober, 1984a

Waller, W.S., Felix, W.L., The Auditor and Leaming from Experience: Some Conjectures, Accounting, Onganizations and Sosiely 9, $\mathrm{Na} 3 / 4,1984 \mathrm{~b}$

Waller, W.S. Felix, W.L, Auditors" Covariation Judgments, Accouming Revitew 52 , april, 1987

Watis, R.L., Zimmerman, J.L. The Demand for and Supply of Accounting Theories: The Market for Excuses, Accowning Rewiew 54, april, 1979

Wats, R.L., Zimmerman, J.L., Positive Accounting Theory. Prentice Hall, Englewood Cliffs, 1986

Whitungton, G., Positiwe Acconnting: A Review Article, Accownting and Businerss Review 17, No. 68,1987

Williamson, O.E., Markets ard Hierarchies: Analysis and Antirust Implication, The Free Press, New York, 1975

Williamson, $O . E$, Wachter, M., Harris, S., Understanding the Employment Relation, Bell Jownal of Economics 6,1975

Wolk, H.I., Francis, JR., Teamey, M.G., Accourling Theory: A Conceptual and Institudional Framework, Kent Publishing Company, Boston, 1984

Zimmennan, J.L., The Cost and Benefits of Cost Allocations, Accoldning Review, juli 1979

Zmijevski, M.E., Hagerman, R.L, An Income Strategy Approach tot the Positive Theory of Accounting Standard Setting/Choice, Jownal of Accounting and Economics, augastus, 1981 



\section{Verantwoording}

Bij de woorbereiding van deze rede heb ik dankbaar gebruik gemaakt van de adviezen van de heren W.F.J. Buijink, D.W. Feenstra en A.M.M. Blommaert.

Voorts dank ik mevrouw F.H.M. Splekerman en de heer E.H.J. Vaassen voor hun onmisbare steun bij de tekstverwerking. 